\title{
Ecological controls on methane emissions from a northern peatland complex in the zone of discontinuous permafrost, Manitoba, Canada
}

\author{
Jill L. Bubier, ${ }^{1}$ Tim R. Moore, Lianne Bellisario, and Neil T. Comer \\ Geography Department and Centre for Climate and Global Change Research, McGill University, Montreal, Quebec, Canada
}

Patrick M. Crill

Institute for the Study of Earth, Oceans, and Space, University of New Hampshire, Durham

\begin{abstract}
Methane emissions were measured by a static chamber technique in a diverse peatland complex in the Northern Study Area (NSA) of the Boreal Ecosystem Atmosphere Study (BOREAS). Sampling areas represented a wide range of plant community and hydrochemical gradients ( $\mathrm{pH} 3.9-7.0$ ). Emissions were generally larger than those reported from other boreal wetland environments at similar latitude. Seasonal average fluxes from treed peatlands (including palsas) ranged from 0 to $20 \mathrm{mg} \mathrm{CH}_{4} \mathrm{~m}^{-2} \mathrm{~d}^{-1}$ compared with 92 to $380 \mathrm{mg} \mathrm{CH}_{4} \mathrm{~m}^{-2} \mathrm{~d}^{-1}$ in open graminoid bogs and fens (with maximum single fluxes up to $1355 \mathrm{mg} \mathrm{CH}_{4} \mathrm{~m}^{-2} \mathrm{~d}^{-1}$ ). Permafrostrelated collapse scars had similarly high $\mathrm{CH}_{4}$ emissions, particularly in the lagg areas where continuous measurements of water table, peat surface elevation, and peat temperature showed that the peat surface adjusted to a falling water table in the abnormally dry 1994 season, maintaining warm, saturated conditions and high $\mathrm{CH}_{4}$ flux later into the season than nonfloating sites. A predictive model for $\mathrm{CH}_{4}$ flux and environmental variables was developed using multiple stepwise regression. A combined variable of mean seasonal peat temperature at the average position of the water table explained most of the spatial variability in $\log \mathrm{CH}_{4}$ flux $\left(r^{2}=0.64\right)$, with height above mean water table (HMWT), water chemistry $\left(K_{\mathrm{corr}}, \mathrm{pH}, \mathrm{Ca}\right)$, tree cover, and herbaceous plant cover explaining additional variance $\left(r^{2}=0.81\right)$. Canonical correspondence analysis (CCA) of combined vascular and bryophyte data with environmental variables showed that $\mathrm{CH}_{4}$ flux was negatively correlated with HMWT, the second axis of vegetation variability, and was only weakly correlated with chemistry, the first axis. Sedge and tree cover were correlated with high and low $\mathrm{CH}_{4}$ fluxes, respectively, while shrub cover was of less predictive value. Microtopographic groupings of hummocks and hollows were separated in terms of $\mathrm{CH}_{4}$ flux at the intermediate ranges of the moisture gradient. These data show that multivariate vegetation analyses may provide a useful framework for integrating the complex environmental controls on $\mathrm{CH}_{4}$ flux and extrapolating single point chamber measurements to the landscape scale using remote sensing. (Key words: $\mathrm{CH}_{4}$ flux, peatland, vegetation, and remote sensing.)
\end{abstract}

\section{Introduction}

The boreal zone is an important area for monitoring trace gas emissions because global climate models predict that the region will experience large changes in temperature and precipitation with increasing atmospheric $\mathrm{CO}_{2}$ concentrations [Hansen et al., 1988]. Boreal wetlands comprise over half the wetland area in the northern hemisphere [Aselmann and Crutzen, 1989]. They develop deep peat deposits because plant production exceeds decomposition in cold, waterlogged environments. However,

\footnotetext{
${ }^{1}$ Now at the Institute for the Study of Earth, Oceans, and Space, University of New Hampshire, Durham.
}

Copyright 1995 by the American Geophysical Union .

Paper number 95GB02379.

0886-6236/95/95GB-02379\$10.00 these large reservoirs of soil carbon are potentially available to the atmosphere as $\mathrm{CH}_{4}$ and $\mathrm{CO}_{2}$ if decomposition becomes greater than production. This is particularly important where peat is currently frozen, and may degrade and decompose rapidly once a thaw cycle is initiated by climate change.

In the zone of discontinuous permafrost, a region that is very sensitive to climate change, it is important to quantify the effect of permafrost degradation on $\mathrm{CH}_{4}$ emissions. Most of the studies of $\mathrm{CH}_{4}$ and permafrost are from the arctic tundra [Bartlett et al., 1992; Whalen and Reeburgh, 1988], which is a very different ecosystem from the boreal region. The boreal region generally has deeper peat deposits than the arctic region, more widespread cover of wetlands, and a wider variety of plant lifeforms with trees, graminoids, and bryophytes dominant in the wetlands [Zoltai, 1988].

Studies to date have identified the problems with estimating $\mathrm{CH}_{4}$ emissions over large landscapes because the temporal and spatial variabilities are extremely high (reviewed in work by 
Bartlett and Harriss [1993]). Processes controlling $\mathrm{CH}_{4}$ emission include water table position, which indicates the degree of anaerobicity in the peat profile, peat temperature, which regulates the rate of microbial activity, substrate type [Svensson and Sundh, 1992; Boone, 1991; Crill et al., 1991] and vegetation, which may enhance total emissions by transport mechanisms and primary production [Chanton and Dacey, 1991]. At the landscape level, several scales of variability (enclosures, towers, and aircraft) and vegetation classification were used successfully in the Hudson Bay Lowland, the Florida Everglades, and the YukonKuskokwim Delta of Alaska to extrapolate $\mathrm{CH}_{4}$ fluxes from the chamber to the landscape scale [Roulet et al., 1994, Bartlett et al., 1989, Bartlett et al., 1992]. Although there was relatively good agreement among the different measurement techniques, these extrapolations were made from wetland classifications without a direct process-oriented relationship between vegetation and gas flux.

In order to quantify $\mathrm{CH}_{4}$ emissions at the landscape level, methods are needed that incorporate physical parameters of moisture and thermal regime with vegetation characteristics, which can be remotely sensed more easily than water table position or peat temperature. This is important because the effect of a $2 \times \mathrm{CO}_{2}$ scenario may affect the hydrology and thermal regime differently depending on the region [Roulet et al., 1992b]. We need to know the importance of each factor and how they are related to vegetation characteristics. Plants may be good predictors for past and future $\mathrm{CH}_{4}$ emissions as well as present conditions because they integrate and are surrogates for longterm patterns of temperature, moisture, and substrate conditions. Previous studies have used correlations of wetland classifications with flux, but have not included a physically based rationale for using vegetation units for $\mathrm{CH}_{4}$ flux extrapolation. Classifications usually do not account for gradients in plant communities within ecosystems or microtopographic differences in hydrology, which are important for explaining spatial variability in $\mathrm{CH}_{4}$ flux [Bubier et al., 1993b] and for integrating the dominant processes that control $\mathrm{CH}_{4}$ flux.

The objectives of this study were to: (1) quantify $\mathrm{CH}_{4}$ emissions from the wide range of peatland soils in the Northern Study Area of the Boreal Ecosystem-Atmosphere Study (BOREAS) near Thompson, Manitoba, as represented by a suite of bogs, fens, peat plateaus and collapse scars in the tower fen complex, (2) determine environmental controls on $\mathrm{CH}_{4}$ emission in order to improve process models which describe the exchange of trace gases between the boreal ecosystem and the atmosphere, and (3) identify the role of plant associations, as integrators of the environmental controls, in predicting $\mathrm{CH}_{4}$ flux using gradient analysis in order to provide a framework for extrapolating $\mathrm{CH}_{4}$ emissions from the chamber to landscape scale.

\section{Study Area}

The peatland complex in this study was chosen for its diverse representation of plant communities, thermal and hydrochemical gradients, and its inclusion of peat plateaus and collapse scars. The field experiment was located in the Northern Study Area of BOREAS, near Thompson, Manitoba $\left(55.91^{\circ} \mathrm{N} .98 .42^{\circ} \mathrm{W}\right)$. The average annual temperature and precipitation for the region are $-3.9^{\circ} \mathrm{C}$ and $585 \mathrm{~mm}$ (232 as snow; 353 as rain). Also, 1994, the year of $\mathrm{CH}_{4}$ flux measurements, was the third driest year on record with $402 \mathrm{~mm}$ of precipitation.
The underlying substrates supporting the wetlands are Glacial Lake Agassiz sediments overlying the regional bedrock of Canadian Shield Pre-Cambrian gneissic granite. Soils are derived predominantly from Glacial Lake Agassiz sediments and consist mostly of clays and organics. Wetlands are common in the region due to poor drainage across the flat terrain. The wetlands include a wide range of types found in northern peatlands from rich fen to bog ( $\mathrm{pH} 7.0$ to 3.9) [Zoltai, 1988]. Plant associations in fens are diverse, dominated by brown mosses (e.g. Drepanocladus, Scorpidium spp.) and sedge species (particularly Carex spp.). Permafrost underlies many of the peatlands; frozen palsas and peat plateaus are dry and wooded with upland plant communities such as black spruce (Picea mariana), feathermosses (e.g., Pleurozium schreberi) and ericaceous shrubs (e.g., Ledum groenlandicum). Areas of permafrost degradation are found interspersed in the frozen features. These collapse scars become bogs (species poor, Sphagnum-dominated communities) if they collapse completely internal to a peat plateau, isolated from ground water; or may develop into fens if they collapse on the edge of peat plateau where ground water intrudes [Vitt et al., 1994; Zoltai, 1993].

Seven major sites were chosen within the large peatland complex representing the range in water chemistry, moisture, plant communities, palsas, peat plateaus and collapse scars. Within each site, collars were placed along moisture and chemistry gradients.

\section{Methods}

$\mathrm{CH}_{4}$ sampling. A total of 124 PVC collars were placed along the moisture, chemistry, and plant community gradients. At four of the sites (bog collapse scar, fen collapse scar, tower fen, and Zoltai fen) boardwalks were installed spanning the environmental gradients to minimize disturbance. $\mathrm{CH}_{4}$ was sampled at each of the collars once a week from early May through mid-September 1994 using a static chamber technique [Crill et al., 1988]. Water was added to the groove in each collar before inserting the chamber in order to make an air-tight seal. Chambers were made of polycarbonate bottles $(26 \mathrm{~cm}$ in diameter; $40 \mathrm{~cm}$ tall; area of exposure $0.053 \mathrm{~m}^{2}$ ) and covered with aluminum foil to reduce heating [Moore and Roulet, 1991]. The neck was sealed with a rubber stopper that contained a glass tube with a $1 \mathrm{~m}$ length of tygon tubing attached to the top to minimize disturbance. Air samples were obtained from each chamber by inserting a polypropylene syringe into the tygon tubing equipped with a three-way stopcock, pumping the piston 4-5 times to mix air in the chamber before a $10-\mathrm{mL}$ sample was taken. Five samples were taken at $4 \mathrm{~min}$ intervals over a 20 -min. period.

Samples were returned to a laboratory in Thompson and analyzed for $\mathrm{CH}_{4}$ within 4-6 hours of collection. After analysis, the syringes were disassembled and allowed to equilibrate with ambient air. Syringe barrels and plungers were reassembled immediately before sampling. Analyses were conducted with a Shimadzu gas chromatograph with a flame ionization detector (FID-GC) using a Porapak Q column. Nitrogen was used as the carrier gas and $\mathrm{CH}_{4}$ standards of 2.35, 211, and 2037 parts per million by volume (ppmv) were used to calibrate. Precision of the analysis (standard deviation as percent of the mean of 10-15 daily repetitions of the standard) was 0.1 to $0.5 \%$ of the standards. Fluxes between 0.1 and $-0.1 \mathrm{mg} \mathrm{m}^{-2} \mathrm{~d}^{-1}$ were not detectable. Fluxes were calculated by linear regression of the 
concentration change in the five samples. If one sample deviated from the line, the flux was recalculated without the outlier. The correlation coefficient of the regression had to be significant to the $95 \%$ confidence limit for $n=4$ or $5\left(r^{2}=0.95\right.$ or 0.87$)$; otherwise the sample was rejected. Sites with ebullition were kept in the data set even if a large increase was observed between two of the samples as long as the correlation coefficient was still significant at $p<0.05$.

Environmental variables. Water table position relative to the peat surface and peat temperature at $10-\mathrm{cm}$ increments from 0 to $50 \mathrm{~cm}$ depth were measured manually once a week at the same time as methane sampling. The height of each collar relative to water table was measured with a tube level referenced to the nearest well. In order to get a more detailed temporal record at selected sites, 14 water level recorders and thermocouples $(10$, $20,50,100 \mathrm{~cm}$ depth) were installed at the four boardwalk sites, placed along the moisture and chemical gradients. Bog shoes constructed of PVC tubing [Roulet et al., 1991] were placed on the peat surface in four locations to measure the surface adjustments of the peat over the season. Data loggers recorded average peat surface elevation, water table position, and peat temperature at 4 depths every 2 hours from mid-May through mid-September. Temperature at the average water table position was determined by calculating mean water table position for the season, then determining the corresponding mean temperature at that depth.

Surface water samples were taken twice at 36 locations during the summer. Samples were collected in triple acid-washed polyethylene bottles and and analyzed within 4 hours in the Thompson laboratory for $\mathrm{pH}$ and specific conductance. Conductivity measurements were adjusted to $20^{\circ} \mathrm{C}$ and corrected for hydrogen ions ( $K_{\mathrm{corr}}, \mu S \mathrm{~cm}^{-1}$; Sjors [1950]). Samples were filtered, stored at $4^{\circ} \mathrm{C}$ and analyzed by atomic absorption spectrophotometry at McGill University for major cations: calcium (Ca), magnesium $(\mathrm{Mg})$, potassium $(\mathrm{K})$, and sodium (Na).

Vegetation sampling. Plant species composition was recorded in each collar by percent cover of vascular plant and bryophyte species [Daubenmire, 1968]. Nomenclature follows Anderson et al. [1990] for true mosses, Anderson [1990] for Sphagnum moss species, Stotler and Crandell-Stotler [1977] for liverworts, Fernald [1950] for vascular plant species. Sites were classified using a modification of the Canadian peatland classification system [Zoltai, 1988; Riley, 1987] that uses vegetation physiognomy (tree, shrub, graminoid) and water chemistry ( $\mathrm{pH}$, calcium, magnesium) as the primary variables: e.g., open sites had $<10 \%$ tree cover; treed sites had $10-30 \%$ tree cover; the $\mathrm{pH}$ of bogs was 3.8-4.7; poor fens 4.5-5.1; intermediate fens 5.1-6.2; rich fens 6.2-7.0. In order to describe small-scale differences in surface elevation, each collar was given a microtopographic designation of hummock, hollow, carpet, or pool as an indirect measure of water table position. Carpets were relatively flat areas where the water table was near the surface and the peat was loosely consolidated. These areas were common where the peat surface was floating. Hummocks and hollows were smaller features $\left(<1-2 \mathrm{~m}^{2}\right)$ in more undulating terrain.

Data analyses. Multiple stepwise regression (SYSTAT package, Wilkinson [1990]) was used to develop a predictive model with the measured environmental variables: (1) water table position, (2) soil temperature, (3) water chemistry ( $\mathrm{pH}, K_{\text {corr }}, \mathrm{Ca}$,
$\mathrm{Mg}$ ), and (4) plant variables by physiognomic group (e.g., tree, shrub, and sedge cover).

Plant species and community data were analyzed by detrended correspondence analysis (DCA) for indirect gradient analysis, and canonical correspondence analysis (CCA) for direct gradient analysis using the CANOCO program [ter Braak, 1990] in order to determine the most important environmental variables explaining vascular and bryophyte species distribution. Cover values of plant species were transformed to an eight-point scale $(\mathrm{l}=0.1-1 \%, 2=1-2 \%, 3=2-5 \%, 4=5-10 \%, 5=10-25 \%, 6=25-50 \%$, $7=50-75 \%, 8=75-100 \%$ ). DCA ordinations were made separately for bryophytes, vascular plant species and the two data sets combined. The same three data sets were used for CCA, which constrains the axes to measured environmental variables. The variables used for each collar were arithmetic mean $\mathrm{CH}_{4}$ flux, height above mean water table (HMWT), $\mathrm{pH}, K_{\mathrm{corr}}, \mathrm{Ca}, \mathrm{Mg}$, shrub cover, herbaceous cover, sedge cover, and tree cover. Five samples were eliminated as outliers because they had unique species and biased the analysis.

\section{Results}

Summary methane data. The range of $\mathrm{CH}_{4}$ flux measurements in the full suite of sites shows that emissions varied spatially both within and between sites (Table 1). For example, within the fen collapse scar, average $\mathrm{CH}_{4}$ fluxes for the season varied from 19.1 to $108.3 \mathrm{mg} \mathrm{CH}_{4} \mathrm{~m}^{-2} \mathrm{~d}^{-1}$. The minimum and maximum fluxes recorded were -0.4 to 1021.1 within that site alone. The standard deviations of the mean (which are a measure of both temporal and small-scale spatial variability within sites) were often $100 \%$ of the mean flux. The summary flux statistics for each site included collars in different microtopographic categories within the same vegetation class. Open graminoid fens had the highest mean seasonal flux (380 $\mathrm{mg} \mathrm{CH}_{4} \mathrm{~m}^{-2} \mathrm{~d}^{-1}$ at ZF3) and the highest instantaneous flux measurement $(1355.1 \mathrm{mg} \mathrm{CH}$ $\mathrm{m}^{-2} \mathrm{~d}^{-1}$ ). Open graminoid bogs and poor fens had the next highest mean flux $\left(60.8\right.$ to $\left.108.3 \mathrm{mg} \mathrm{CH}_{4} \mathrm{~m}^{-2} \mathrm{~d}^{-1}\right)$. Treed sites had the lowest mean flux ( $<20 \mathrm{mg} \mathrm{CH}_{4} \mathrm{~m}^{-2} \mathrm{~d}^{-1}$ ) of all sites, with the driest hummocks and palsas occasionally showing slight consumption (-1.5 $\mathrm{mg} \mathrm{CH}_{4} \mathrm{~m}^{-2} \mathrm{~d}^{-1}$ at TF2).

Temporal patterns of $\mathrm{CH}_{4}$ flux were different among sites (Figure 1). Some sites (e.g., TF4 Figure 1a) had smooth seasonal increases with peak fluxes around day 240 (mid-August) generally increasing with peat temperature. At the Zoltai fen (ZF4; Figure 1b) high fluxes were recorded as early as day 187 , dropped at day 195 following a large rise in water table and corresponding drop in peat temperature (Figure 4a). Fluxes recovered quickly and generally remained high until day 240 , when they tapered off, but were still relatively high even in midSeptember. Other sites, especially the open water laggs of collapse scars (e.g., RB Figure 1c), showed erratic seasonal patterns, probably due to ebullition of methane at different times. These sites also had a large flux of methane in early spring, probably from $\mathrm{CH}_{4}$ trapped beneath the ice and released as the ice melted. These large early season fluxes often dominated the seasonal flux.

Environmental variables. Summary statistics for water table position and peat temperature are shown in Table 1. The relationships among the mean, median, and modes are not the same for all the sites. At many sites, the most frequent position 
Table 1. Summary $\mathrm{CH}_{4}$ Flux Statistics for Period From May 15 to September 15, 1994

\begin{tabular}{|c|c|c|c|c|c|c|c|c|c|c|c|}
\hline \multirow[t]{2}{*}{ Site } & \multirow[t]{2}{*}{ Class } & \multirow{2}{*}{$\begin{array}{l}\text { Mean } \\
\mathrm{CH}_{4} \text { Flux } \\
\text { (s.d.) }\end{array}$} & \multirow{2}{*}{\multicolumn{2}{|c|}{ 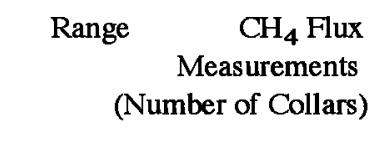 }} & \multirow[t]{2}{*}{ Micro } & \multicolumn{3}{|c|}{$\begin{array}{l}\text { Water Table } \\
\text { Position }(\mathrm{cm})\end{array}$} & \multicolumn{3}{|c|}{ Temperature $\left({ }^{\circ} \mathrm{C}\right)$} \\
\hline & & & & & & $\begin{array}{l}\text { Mean } \\
\text { (s.d.) }\end{array}$ & Median & Mode & $\begin{array}{l}\text { Mean M } \\
\text { (s.d.) }\end{array}$ & Median & Mode \\
\hline $\mathrm{BCl}$ & OlsB & $96.9(167.2)$ & $2.2-1230.5$ & $66(5)$ & c & $-6.4(4.5)$ & -9 & -10.4 & $12.1(2.6)$ & 6) 12.2 & 13.1 \\
\hline $\mathrm{BC3}$ & OlsB & $55.4(98.3)$ & $2.3-691.3$ & $84(5)$ & hw & $-11.1(4.2)$ & -8.2 & -8.0 & $8.4(3.7)$ & 9.3 & 9.9 \\
\hline $\mathrm{FC} 1$ & OgPF & $108.3(145.3)$ & $9.3-1021.1$ & $85(5)$ & $\mathrm{c}$ & $-11.2(3.1)$ & -9.9 & -8.1 & $11.8(2.4)$ & ) 11.8 & 11.7 \\
\hline $\mathrm{FC} 2$ & OgPF & $60.6(46.9)$ & $1.2-412.1$ & $85(5)$ & c & $-8.1(3.5)$ & -5.8 & -5.0 & $11.1(3.3)$ & 12.1 & 11.4 \\
\hline $\mathrm{FC} 3$ & TlsPF & $19.1(25.5)$ & $-0.4-136.2$ & $73(5)$ & hk & $-20.1(2.3)$ & -20.6 & -14.0 & $5.4(4.0)$ & 7.1 & 8.5 \\
\hline FC4 & $\mathrm{OgF}$ & $92.3(55.9)$ & $5.1-269.3$ & $88(5)$ & $\mathrm{c}$ & $-2.2(5.3)$ & -0.4 & 2.1 & $12.4(2.1)$ & 12.6 & 9.9 \\
\hline $\mathrm{RBC}$ & $\mathrm{OgB}$ & $86.8(30.7)$ & $10.1-483.4$ & $126(9)$ & c & *-9.3 (3.2) & -9.1 & - & *13.5 (2.1) & 13.6 & - \\
\hline $\mathrm{TF} 2$ & TisF & $16.3(14.3)$ & $2.1-92.9$ & $81(5)$ & hw & $0.1(2.7)$ & 0 & -3.3 & $6.8(2.8)$ & 7.6 & 8.1 \\
\hline $\mathrm{TF} 2$ & TtsF & $5.7(5.4)$ & $-1.5-19.7$ & $57(5)$ & hk & $-30.4(2.4)$ & -30.5 & -33.4 & $9.1(3.2)$ & 9.5 & 9.2 \\
\hline TF4 & $\mathrm{OlsF}$ & $55.3(37.5)$ & $6.3-138.2$ & $144(9)$ & $\mathrm{c}$ & $-9.6(4.2)$ & -9.9 & -7.9 & $14.3(3.3)$ & 14.3 & 12.7 \\
\hline $\mathrm{ZF} 1$ & OlsF & $60.5(47.3)$ & $5.5-182.1$ & $51(3)$ & hw & $-7.7(3.9)$ & -6.4 & -13.7 & $13.7(3.3)$ & 13.9 & 9.5 \\
\hline $\mathrm{ZF} 2$ & OlsF & $76.8(53.7)$ & $0.7-225.3$ & $81(5)$ & hw & $-7.6(3.7)$ & -8.3 & -4.5 & $12.5(1.9)$ & 12.8 & 10.9 \\
\hline $\mathrm{ZF3}$ & $\mathrm{OgF}$ & $210.2(152.2)$ & $16.8-1355.1$ & $112(7)$ & $\mathrm{c}$ & $2.6(2.6)$ & 2.2 & -0.3 & $13.7(2.2)$ & 13.7 & 15.9 \\
\hline
\end{tabular}

Flux statistics are measured in milligrams methane per square meter per day. Statistics for water table position (in centimeters) and peat temperature (in degrees C) at the water table as recorded every 2 hours from May to September. Negative numbers indicate water table is below the peat surface; Asterisk* denotes weekly manual measurements only. Microtopography (micro) indicates location of the well and thermocouples: hk = hummock; hw $=$ hollow; $c=$ carpet. Site mean $\mathrm{CH}_{4}$ fluxes include collars in different microtopographic categories within the same vegetation class. See Table 3 for site and class designations.

of the water table (mode) was lower than the mean or the median. At other sites, particularly some of the collapse scars, the mode and median were higher than the mean. The three statistical measures were more similar for temperature with the exception of the Zoltai fen sites (ZF1, ZF2, ZF3). ZF1 and ZF3 had very similar mean temperatures at the water table. But the most frequent temperature for $\mathrm{ZF} 1$, located at the base of a small palsa, was $9.5^{\circ} \mathrm{C}$ compared to $15.9^{\circ} \mathrm{C}$ for $\mathrm{ZF3}$, which was a saturated sedge-dominated area. The mean $\mathrm{CH}_{4}$ fluxes for $\mathrm{ZF3}$ were over three times higher than ZF1. Although ZF3 was wetter on average by $9 \mathrm{~cm}$, the temperature distributions may have also contributed.

The seasonal patterns of water table position, peat temperature and peat surface adjustments are shown in Figures 2-4. A typical example of the large difference in thermal regime on the microtopographic scale is shown in the hummock/hollow peat temperatures at the tower fen (Figure 2). At $10 \mathrm{~cm}$ below the peat surface the hummock was above the water table and consistently warmer than the hollow (Figure 2a). The hummock was also more variable, reflecting diurnal changes in air temperature. The hollow at $10 \mathrm{~cm}$ depth was colder than the hummock, but less variable, reflecting the large heat capacity of water relative to air. At $1 \mathrm{~m}$ depth, both the hummock and hollow were frozen until day 200 when they both warmed gradually to a maximum of $5^{\circ} \mathrm{C}$. Comparing seasonal temperatures at the average position of the water table, which was $10 \mathrm{~cm}$ for the hollow and $50 \mathrm{~cm}$ for the hummock (Figure $2 \mathrm{~b}$ ), the hollow was consistently warmer than the hummock. The $\mathrm{CH}_{4}$ flux from the hollow was always greater than the hummock throughout the season, and the mean flux was 3 times that of the hummock (Table 1).

A similar pattern was observed in the fen collapse scar where the temperature at the water table was on average $7^{\circ} \mathrm{C}$ warmer in the carpet (FC4) than the hummock (FC3), although the mode was only $1^{\circ} \mathrm{C}$ higher (Table 1 ; Figure 3 ). Peak seasonal temperatures were only $10^{\circ} \mathrm{C}$ for the hummock at $20 \mathrm{~cm}$ compared with $17^{\circ} \mathrm{C}$ for the hollow at $10 \mathrm{~cm}$. The average water table position was $2.2 \mathrm{~cm}$ below the peat surface for the hollow, compared with $20 \mathrm{~cm}$ for the hummock. Corresponding $\mathrm{CH}_{4}$ fluxes were over 4 times higher in the hollow (Table 1).

The close relationship between the seasonal patterns for water table position and temperature at the water table are shown in Figure 4a. At the Zoltai site (ZF3), the peat surface adjusted to the water table even though the water table dropped about $15 \mathrm{~cm}$ from day 190 to day 260 (Figure 4b). The areas of floating peat maintained nearly saturated conditions due to the peat surface adjustments in all measured sites. These sites also maintained higher $\mathrm{CH}_{4}$ fluxes for a longer period of time (e.g., Figurelb), compared with nonfloating sites where the water table dropped 20 $\mathrm{cm}$ below the surface in the unusually dry year (Figure1a).

Spatial variability and predictive model for $\mathrm{CH}_{4}$ flux. In 
Tower fen
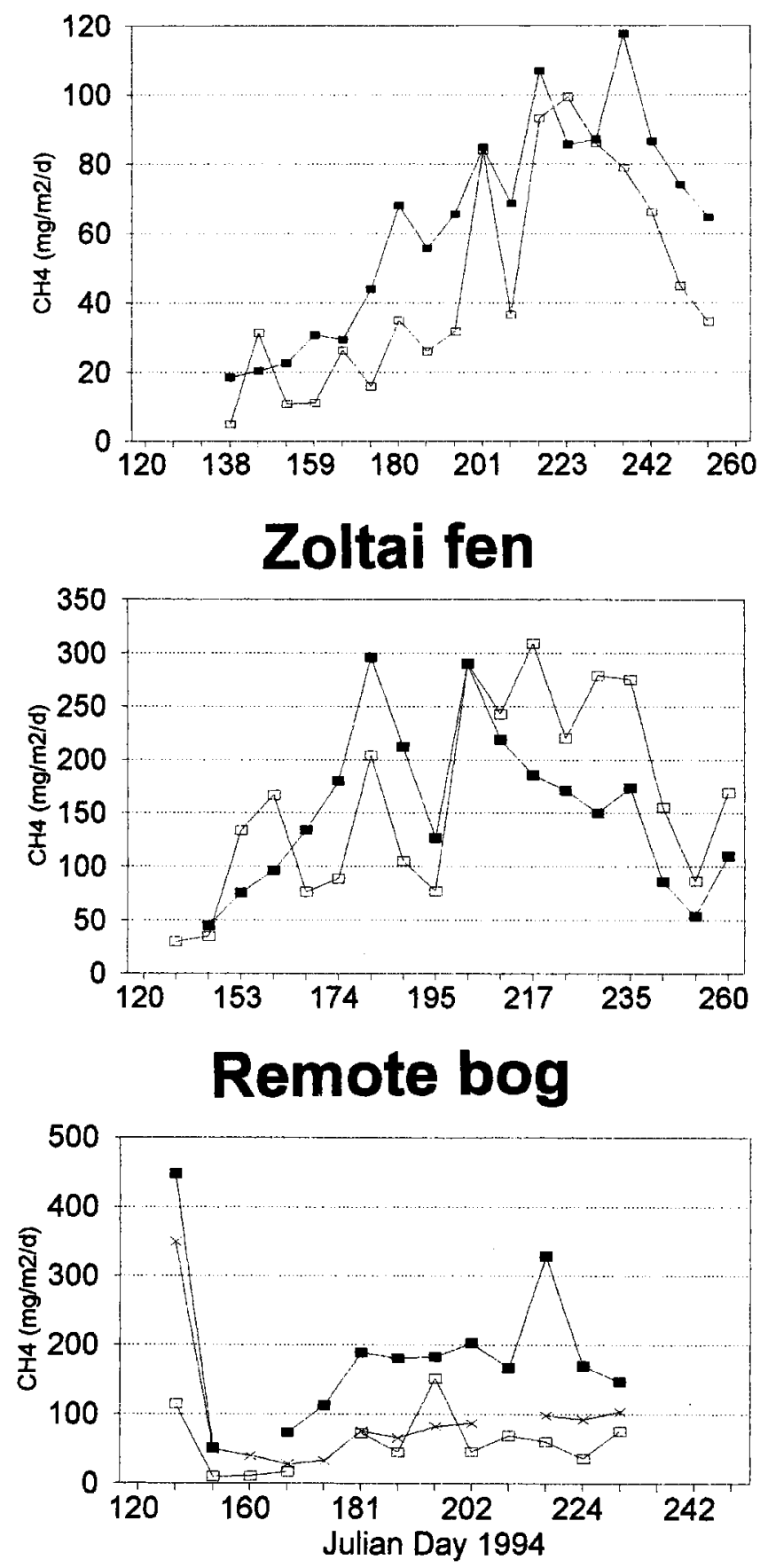

Figure 1. Seasonal patterns of $\mathrm{CH}_{4}$ flux at three of the wettest sites representing the range in chemistry and plant communities: (a) tower fen (TF4), open low shrub rich fen; (b) Zoltai fen (ZF3), open graminoid intermediate fen; (c) bog collapse scar (RBC), open graminoid bog. Each point represents a flux measurement for a single representative collar.

order to determine the best predictive relationships between environmental variables and $\mathrm{CH}_{4}$ flux, a couple of different approaches were tested. The first was to correlate wetland vegetation classification with spatial variability of $\mathrm{CH}_{4}$ flux; the second was to include all the environmental parameters in a multiple regression model to rank the relevant factors in order of importance.

The spatial variability in $\mathrm{CH}_{4}$ flux was evident along a transect of the tower fen from the open water lagg area adjacent to a peat plateau, through a dry, treed area, and into the wet, low shrub area of the fen (Figure 5). Although the open water areas had the highest fluxes and the treed fen the lowest, the spatial variability within the three wetland classes was still high. Much of the variability could be explained by microtopography in the open low shrub area. By taking all the $\mathrm{CH}_{4}$ collar vegetation and classifying according to vegetation physiognomy and chemistry (Figure 6), it is evident that all treed areas (including permafrost peat plateaus and palsas) had very low seasonal average $\mathrm{CH}_{4}$ fluxes (range of mean fluxes $0-20$ (s.d. 1-25) $\mathrm{mg} \mathrm{CH}_{4} \mathrm{~m}^{-2} \mathrm{~d}^{-1}$ ) and that the open graminoid fens had the highest (range 92-380 (s.d. 56-152) $\mathrm{mg} \mathrm{CH}_{4} \mathrm{~m}^{-2} \mathrm{~d}^{-1}$ ). Other open low shrub, graminoid and open water areas had mean fluxes ranging from 0 to150 (s.d. 1-167) $\mathrm{mg} \mathrm{CH}_{4} \mathrm{~m}^{-2} \mathrm{~d}^{-1}$, a large range in fluxes that could not be explained solely by general peatland classification.

A model was developed for predicting $\log \mathrm{CH}_{4}$ flux from the measured environmental variables using stepwise multiple regression (Table 2). The variables that were included in the model were the ones significant at $p<0.05$. All others were

\section{Tower fen}

hummock and hollow $10,100 \mathrm{~cm}$

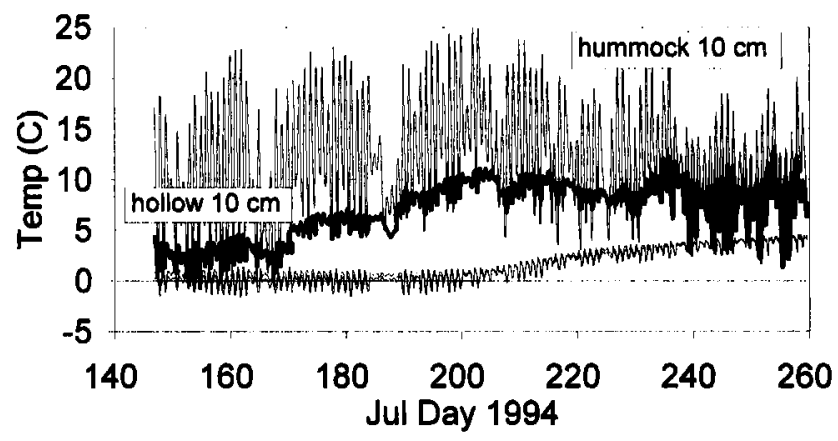

hummock and hollow at mean wt

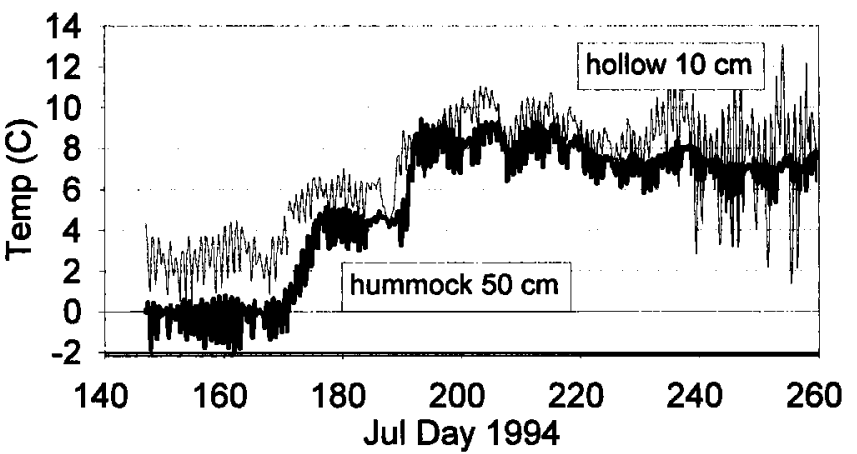

Figure 2. Seasonal patterns of peat temperatures in hummock and hollow locations: (a) tower fen (TF2) temperatures at 10 and $100 \mathrm{~cm}$ below the peat surface; hollow temperatures at $10 \mathrm{~cm}$ are in bold; (b) same TF2 temperatures at the mean water table position ( $10 \mathrm{~cm}$ for hollow; $50 \mathrm{~cm}$ for hummock in bold). 


\section{Fen collapse scar carpet (Warnstorfia exannulata)}

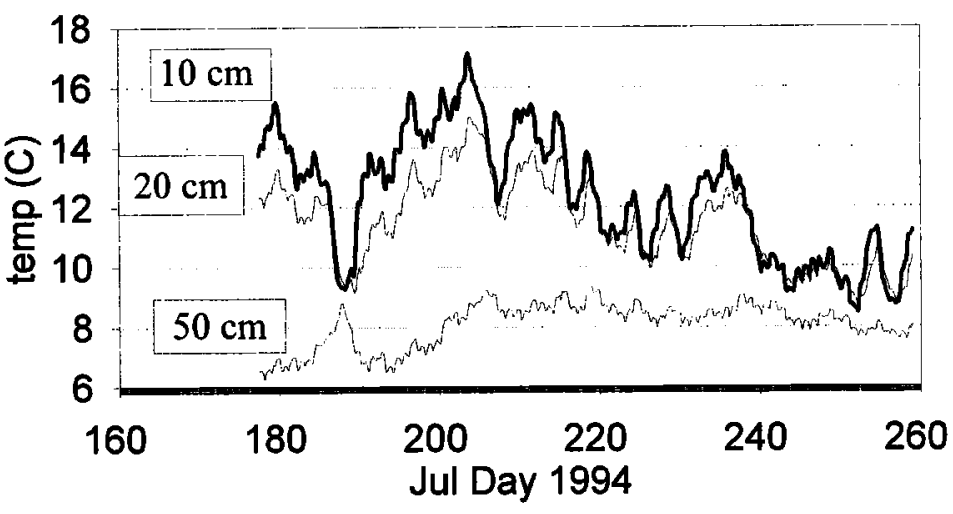

hummock (Sphagnum fuscum)

b

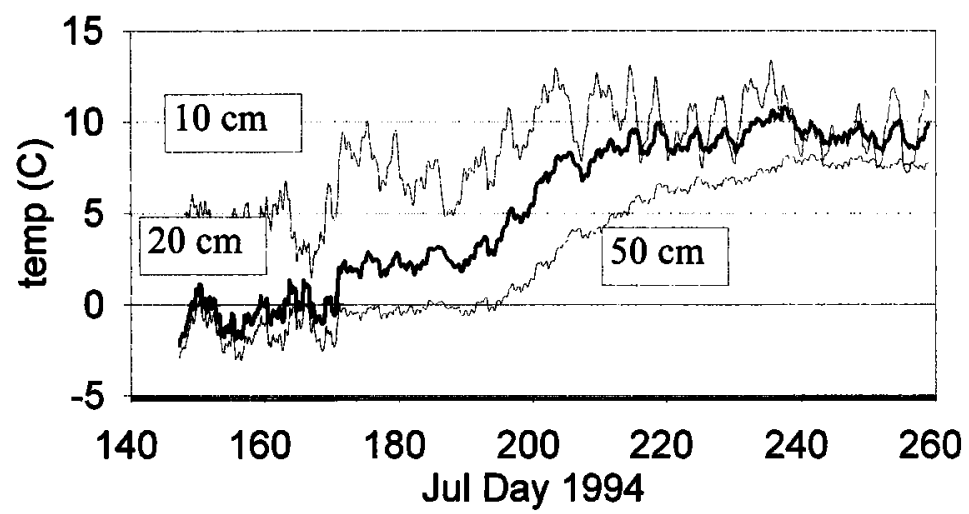

Figure 3. (a) Carpet peat temperatures at three depths in the fen collapse scar (FC4) with temperature at water table position (10 cm depth) in bold; (b) hummock temperatures at the fen collapse scar (FC3) with temperature at water table position ( $20 \mathrm{~cm}$ depth) in bold.

eliminated. In order of importance, the best predictive variables were temperature at mean water table position (meantemp), height above mean water table (HMWT), corrected conductivity $\left(K_{\text {corr }}\right)$, herbaceous cover (herb), and tree cover (tree). Sedge cover was eliminated because it was strongly correlated with herbaceous cover; $\mathrm{pH}$ and $\mathrm{Ca}$ were correlated with $K_{\text {corr }}$ and shrub cover did not add anything to the model. The correlation coefficient for the model was $r^{2}=0.81(p=0.001 ; n=105)$. Mean temperature at the average water table position, which was a combined variable of moisture and thermal regime, explained most of the variability (63\%). Water chemistry, as represented

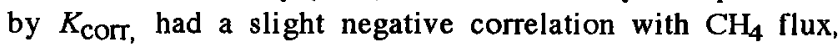
indicating that the highest $\mathrm{CH}_{4}$ flux collars were not associated with the highest $\mathrm{pH}, \mathrm{Ca}$, or $K_{\text {corr }}$ environments. Tree and herbaceous cover contributed to the model after moisture was accounted for, suggesting that the plant type itself may play a role in $\mathrm{CH}_{4}$ flux.

The relationships between seasonally averaged $\log \mathrm{CH}_{4}$ flux, peat temperature, and water table are shown in Figure 7. Log mean $\mathrm{CH}_{4}$ flux versus mean temperature at the water table was the best individual predictor $\left(r^{2}=0.63\right)$. Temperature at a standard peat depth, such as 10 or $20 \mathrm{~cm}$, did not correlate well with $\mathrm{CH}_{4}$ flux. Height above mean water table alone was the second best individual predictor $\left(r^{2}=0.54\right)$. Most of the variability appeared to occur in the sites where the water table ranged from the peat surface to $10 \mathrm{~cm}$ below. This suggests that even small differences in hydrology and temperature can have a large effect on $\mathrm{CH}_{4}$ flux, particularly where the water table is near the peat surface. Other factors such as peat type, ebullition, plant production, and transport mechanisms may also be responsible for variable fluxes in saturated environments.

Vegetation and $\mathrm{CH}_{4}$ flux. The multiple regression model incorporated the important processes explaining spatial variability in $\mathrm{CH}_{4}$ flux. However, most of the variables, such as temperature and water table position, are not independent and cannot be sensed remotely. Wetland classifications separated the major ranges in $\mathrm{CH}_{4}$ flux, but did not explain within-class variability. Further analyses were conducted to see if vegetation types, which are distinguishable with remote sensing, can be tied directly to the most important processes explaining $\mathrm{CH}_{4}$ flux.

The dominant bryophyte and vascular plant species for the major $\mathrm{CH}_{4}$ sampling sites are listed by microtopographic category 


\section{Zoltai fen}

water table and peat temperature


Figure 4. (a) Zoltai fen (ZF3) water level and peat temperature at $10 \mathrm{~cm}$ below peat surface; (b) ZF3 peat surface elevations (bold) and water table position relative to an arbitrary datum.

in Table 3 (see Appendix A for species list). Associated water chemistry variables are also listed. High $\mathrm{pH}$ and calcium sites had the highest species diversity. In the rich fens ( $\mathrm{pH}$ 6.2-7.0), the bryophytes were dominated by members of the Amblystegicaceae family or "brown mosses". Bogs and poor fen sites ( $\mathrm{pH}$ 3.8- 4.7) were dominated by Sphagnum moss species. The vascular plants were also more diverse in the rich fens with over 4 times as many shrub, sedge, and other herbaceous species. The driest sites were dominated by trees, while the wettest were sedge-dominated, primarily by Carex species. Shrubs were absent from the very wettest sites, but spanned a greater moisture gradient than either trees or sedges.

Multivariate analyses of the vegetation data were used to further refine the $\mathrm{CH}_{4}$ flux-vegetation relationships beyond general peatland classifications. The CCA ordination (Figure 8) shows that the vegetation is grouped by both chemistry $(\mathrm{pH}$, $K_{\text {corr }}, \mathrm{Ca}$ ) and height above mean water table (HMWT) at the microtopographic scale. Each point on the biplot represents an individual collar (Figure $8 \mathrm{a}$ ) or species (Figure $8 \mathrm{~b}$ ) and the arrows or vectors are the environmental variables. The weighted averages of plots or species can be inferred by projecting a perpendicular line from the point to the arrow. The intersection of the species or plot with the environmental vector indicates the center of species or plot distribution along that environmental gradient. The center of the ordination diagram indicates the mean value for each environmental variable. Therefore the arrows extend in both directions even though only the positive direction is shown. The horizontal axis 1 is the primary gradient of vegetation variability and arrows closest to axis 1 are the most important explanatory environmental variables. The vertical axis 2 is the second most important gradient. The greater the angle between two environmental vectors, the less likely they are related to one another; the smaller the angle, the greater the likelihood of collinearity. Opposing directions indicate negative correlation.

Ordinations were created for the bryophytes and vascular plants separately and together. Although the separate ordinations showed some differences in the responses of the different lifeforms to the environmental variables, the combined analysis was the best representation of the data. In the original analyses, overall herbaceous and shrub cover were eliminated because the interset correlations were not significant.

The combined bryophyte-vascular plant CCA (Figure 8) shows that chemistry variables are most closely associated with axis 1 , with open low shrub fen hollows grouped at the highest end of the $\mathrm{pH}, \mathrm{Ca}$, and $K_{\text {corr }}$ gradients (The interset correlations for these variables are 894,861 , and 814 , respectively; possible range for low to high correlation between environmental variables and species distribution is $0-1000$ ). All fen collars are on the right half of the ordination and all bog collars are on the left. Axis 2 is primarily a moisture gradient with treed bogs and fens located in the upper half of the biplot toward the driest end of the gradient. Open low shrub bog hummocks are also in the upper left, indicating that they are drier than average, but not as dry as treed sites. Low shrub sites are not very well correlated with high or low $\mathrm{CH}_{4}$ flux, since they are found in an intermediate position along the moisture axis 2 . Low shrub fen hollows, for example, are found at sites that have average, or

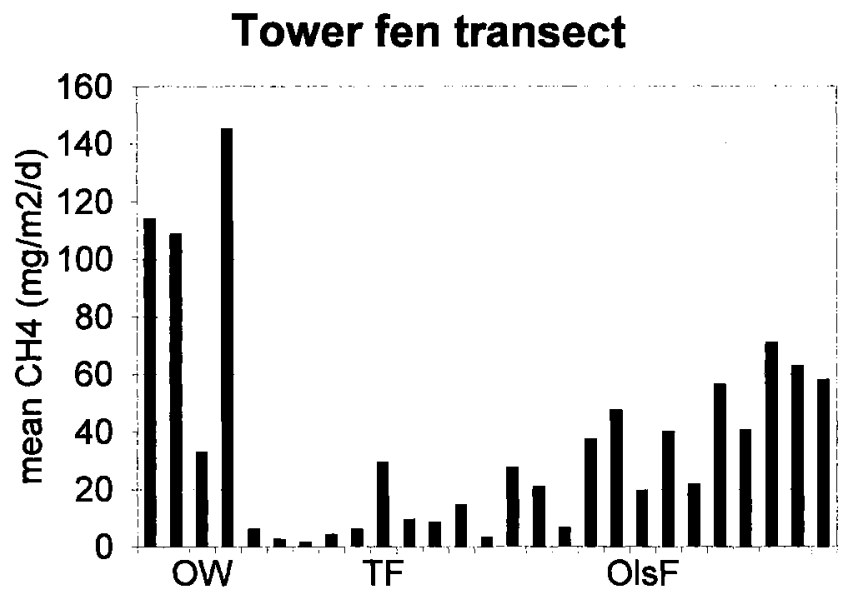

collars 1-25

Figure 5. Spatial variability of $\mathrm{CH}_{4}$ flux at tower fen. Each bar respresents mean seasonal $\mathrm{CH}_{4}$ flux for a single collar. Collar sites are designated a peatland class based on vegetation physiognomy and water chemistry as defined in Table 3 . Classifications are based on work by Riley [1987]. OW = open water lagg area; $\mathrm{TF}=$ treed fen; OlsF = open low shrub fen. 


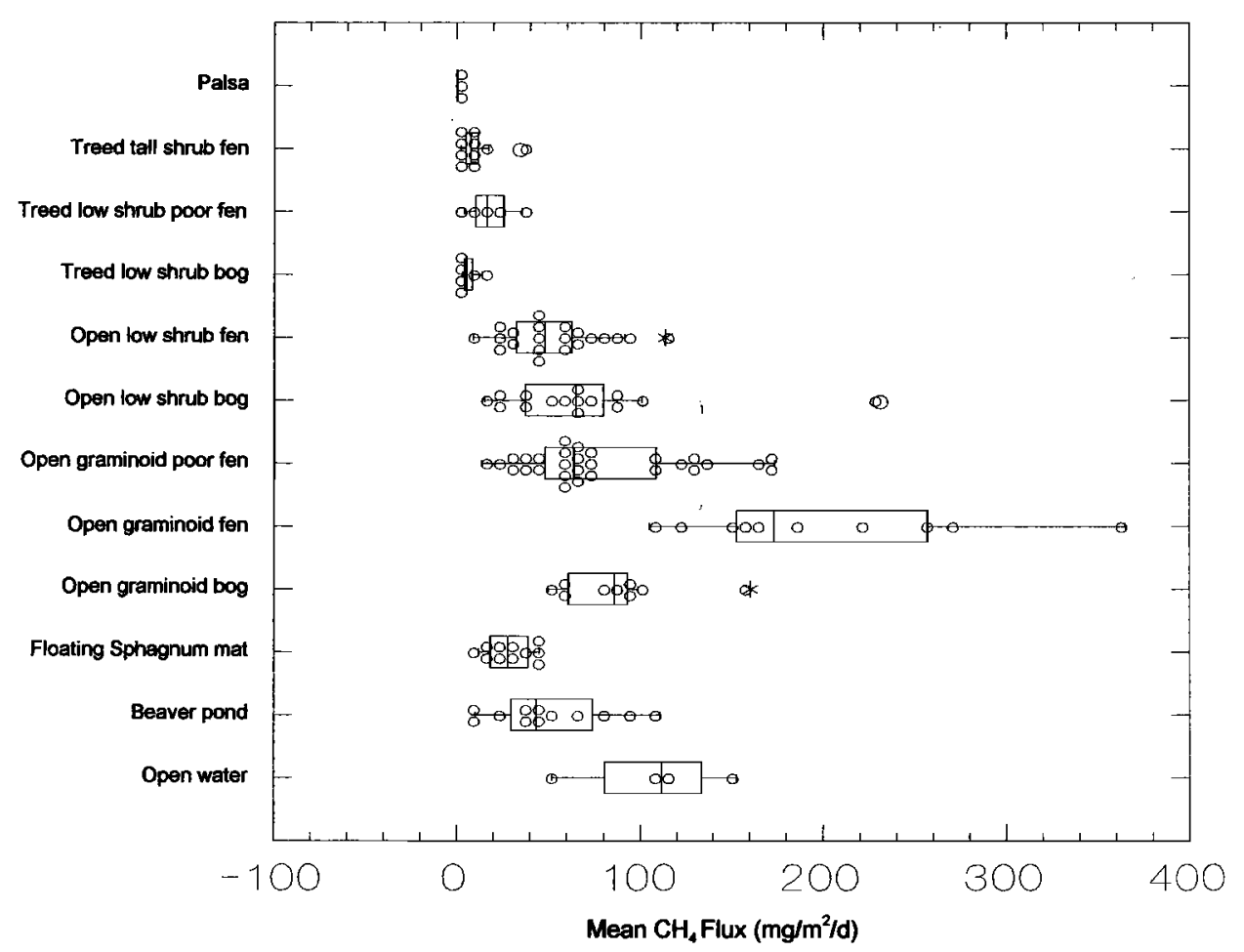

Figure 6. Mean $\mathrm{CH}_{4}$ flux by site classifications. Treed sites have significantly lower fluxes than open graminoid sites, but large variability still exists within the open low shrub and graminoid classes. Microtopographic groupings are included in vegetation classes. Beaver pond data are diffusive fluxes only from N. Roulet et al. (unpublished BOREAS data, 1995); Palsa data are from K. Savage (unpublished BOREAS data, 1995). Each point represents mean $\mathrm{CH}_{4}$ flux for each collar; quartiles and class means are noted by bars.

slightly lower than average, $\mathrm{CH}_{4}$ flux if a perpendicular line is drawn from those points to the $\mathrm{CH}_{4}$ flux vector.

$\mathrm{CH}_{4}$ flux and sedge cover (shown as one arrow since they were very close together) are negatively correlated with HMWT and tree cover. (Interset correlations for HMWT, tree cover, sedge cover, and $\mathrm{CH}_{4}$ flux are $837,687,-633$, and -546 respectively). Sedge and tree cover are most strongly correlated with axis 3, indicating the extreme ends of the moisture gradient. The highest $\mathrm{CH}_{4}$ flux collars are in two groups, open graminoid fens and bogs. These sites are hollows, carpets, and pools in a continually saturated condition. Since both graminoid bog and fen collars are associated with high $\mathrm{CH}_{4}$ flux, chemistry does not

Table 2. Stepwise Multiple Regression for Predicting Seasonal Average $\mathrm{CH}_{4}$ Flux From Environmental Variables

\begin{tabular}{lccccccc}
\hline Variable & Coefficient & Std Error & Std Coefficient & Tolerance & $\mathrm{T}$ & $\mathrm{P}(2$ Tail) & Cumulative $r^{2}$ \\
\hline Mean Temp & 0.098 & 0.014 & 0.464 & 0.448 & 6.943 & 0.0001 & 0.642 \\
HMWT & -0.003 & 0.001 & -0.250 & 0.454 & -3.767 & 0.0001 & 0.721 \\
$K_{\text {corr }}$ & -0.004 & 0.001 & -0.344 & 0.773 & -6.763 & 0.0001 & 0.764 \\
Herb & 0.004 & 0.001 & 0.212 & 0.756 & 4.132 & 0.0010 & 0.793 \\
Tree & -0.004 & 0.002 & -0.111 & 0.717 & -2.110 & 0.0370 & 0.812 \\
\hline
\end{tabular}

Dependent variable is $\log$ mean $\mathrm{CH}_{4} \mathrm{flux}$ (milligrams per square meter per day); $\mathbf{n}=105$ collars; $r^{2}=0.81 ;$ standard error of the estimate $=0.22$. Variables are listed in order of importance in the model. Variable names are mean temperature at the water table (Mean Temp); height above mean water table (HMWT); corrected conductivity of surface water $\left(K_{\text {corr }}\right.$; percent herbaceous plant cover (Herb); and percent tree cover (Tree); Percent cover of sedges was strongly correlated with herb cover; Calcium and magnesium were correlated with $K_{\text {corr }}$. Std Error $=$ standard error of the coefficient; std coefficient $=$ standardized coefficient; $T=$ test of significance of the correlation between dependent and independent variables; $P=$ probability. 


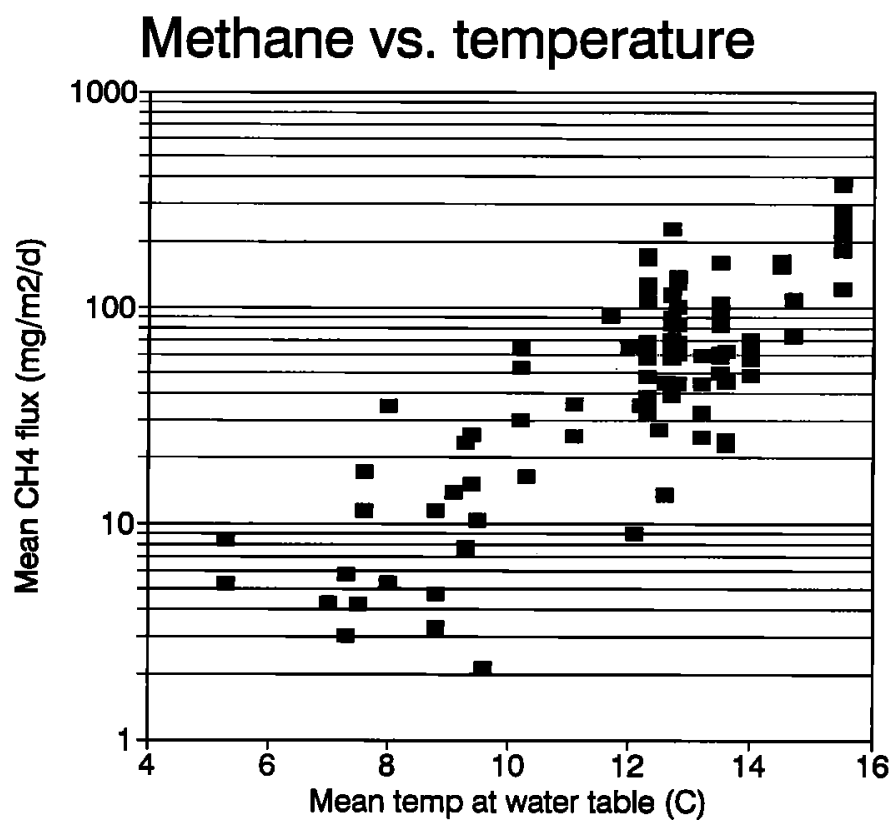

Methane vs. water table

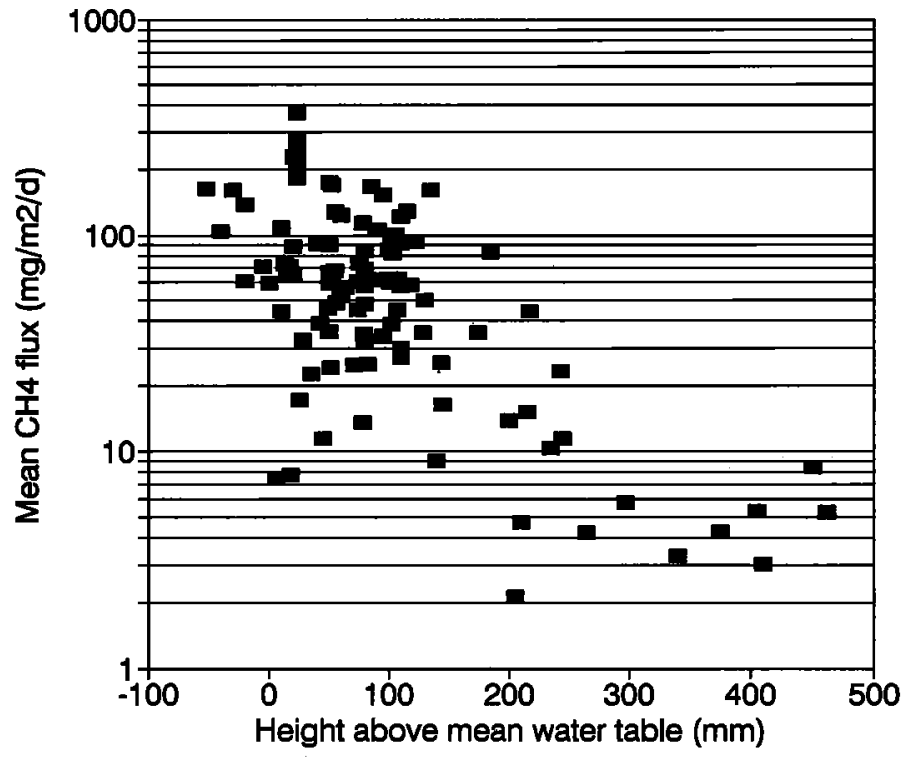

Figure 7. (a) Mean $\mathrm{CH}_{4}$ flux versus mean temperature at mean position of water table (regression). Each point represents seasonal mean values for an individual collar. $\mathrm{Log} \mathrm{CH}_{4}$ flux $=$ 0.16 temp $-0.35 ; r^{2}=0.63 ;$ standard error of estimate $=0.28$; standard error of $x$ coeff $=0.0003$; b) Mean $\mathrm{CH}_{4}$ flux versus mean water table position (regression). $\mathrm{Log} \mathrm{CH}_{4}$ flux $=-0.003$ HMWT $+2.01 ; r^{2}=0.54 ;$ standard error of estimate $=0.32$; standard error of $x$ coeff $=0.0003$.

have a strong correlation with $\mathrm{CH}_{4}$ flux across the full moisture gradient. But at the wettest end of the gradient, the intermediate fen collars have somewhat higher fluxes. The first three axes combined explain $70 \%$ of the species environment correlation (eigenvalues for axes 1,2 , and 3 are $0.72,0.54$, and 0.43). A Monte Carlo permutation test showed that the first and second axes are statistically significant $(p<0.01)$.
The combined ordination for species and environmental variables shows that brown mosses such as Scorpidium scorpioides, Calliergon giganteum, Cinclidium stygium, Limprichtia revolvens, and Meesia triquetra, and vascular plants such as Carex interior, C. lasiocarpa, occur in high $\mathrm{pH}$ environments, particularly in wetter fen hollows. Salix pedicillaris, Tomenthypnum nitens, Sphagnum warnstorfii dominate the drier, fen hummocks. Picea mariana, Larix laricina, Carex disperma, Ledum groenlandicum, and Pleurozium schreberi are common in treed bogs and fens, palsas, and peat plateaus. Polytrichum strictum, Vaccinium vitis-idaea, Dicranum polysetum, and Rubus chamaemorus are found in drier open low shrub hummocks as well as treed bogs. Some shrub species, such Ledum groenlandicum, occur only in dry, low $\mathrm{CH}_{4}$ flux environments, while others, such as Chamaedaphne calyculata and Betula pumila var. glandulifera, are found in a wider range of moisture conditions and are not good predictors of $\mathrm{CH}_{4}$ flux.

Sedges, such as Eriophorum spp., Carex rostrata, C. aquatilis, C. limosa $a_{1}$ and mosses such as Sphagnum riparium, Warnstorfia exannulata, and $W$. fluitans are associated with high $\mathrm{CH}_{4}$ flux and found in open graminoid bogs and poor to intermediate fens. These species have a much narrower moisture range than other plants, particularly the shrubs. Many of these graminoid sites are within collapse scars or along the edge of permafrost features within lagg areas.

\section{Discussion}

Temporal variability in physical parameters. The nearly continuous record of water table and temperature in this study provided an opportunity to examine temporal variability at a fine scale of resolution. These data showed the close relationship on a daily basis between changes in temperature and water table position (Figure 4a). Continuous measurements of water table and temperature have been used successfully in other studies to model the influence of climate on $\mathrm{CH}_{4}$ flux [Frolking and Crill, 1994]. The data in this study showed that the most frequent temperature or water table position was occasionally a better predictor of $\mathrm{CH}_{4}$ flux than the mean (e.g., ZF1 and ZF3). The other important continuous measure in this study was the movement of the peat surface relative to the water table. In several sites, the peat surface adjusted to the drop in water table as much as $15 \mathrm{~cm}$, thereby maintaining warmer, saturated conditions, even in an abnormally dry year. This has important implications for climate change scenarios, where floating peat surfaces may not experience as large a decrease in $\mathrm{CH}_{4}$ emissions as nonfloating surfaces [Roulet et al., 1992b].

The temporal variability in $\mathrm{CH}_{4}$ emissions was large as noted in other studies [e.g.,Whalen and Reeburgh, 1992]. Although the seasonal pattern generally followed an increase in peat temperature, a few interesting patterns were worth noting. Some sites experienced a large pulse of $\mathrm{CH}_{4}$ in the early spring, where thick ice cover occurred over open water or loosely consolidated peat (Figure1c). Several sites also experienced large bubbles of $\mathrm{CH}_{4}$ during the season. The other interesting pattern was the more prolonged period of high $\mathrm{CH}_{4}$ emission at sites with floating peat surfaces (Figure1b). These sites generally had higher sedge cover as well, which may have contributed to the higher emissions.

Permafrost dynamics and landscape evolution. The degradation of permafrost and formation of collapse scars are 
Table 3. Characteristics of $\mathrm{CH}_{4}$ Sampling Sites by Wetland Class and Microtopographic Category

\begin{tabular}{|c|c|c|c|c|c|c|c|c|c|}
\hline Site & Class & Hummock & Hollow & Carpet & $\mathrm{pH}$ & $K_{\text {corr }}$ & $\mathrm{Ca}$ & $\mathrm{Mg}$ & Number \\
\hline $\mathrm{BC} 1$ & OlsB & & & $\begin{array}{l}\text { Sphagnum riparium } \\
\text { Chamaedaphne calyculata } \\
\text { Carex paupercula } \\
\text { Vaccinium oxycoccus }\end{array}$ & $\begin{array}{c}4.2 \\
(0.1)\end{array}$ & $\begin{array}{l}47.2 \\
(8.5)\end{array}$ & $\begin{array}{c}2.86 \\
(0.29)\end{array}$ & $\begin{array}{c}0.48 \\
(0.09)\end{array}$ & 14 \\
\hline $\mathrm{BC} 3$ & ${ }_{C}^{\text {OlsB }}$ & $\begin{array}{l}\text { Sphagnum fuscum } \\
\text { Chamaedaphne calyculata } \\
\text { Smilacina trifolia }\end{array}$ & $\begin{array}{l}\text { Sphagnu } \\
\text { Cladopoc } \\
\text { Vacciniu }\end{array}$ & $\begin{array}{l}\text { stifolium } \\
\text { luitans } \\
\text { occus }\end{array}$ & $\begin{array}{c}4.1 \\
(0.1)\end{array}$ & $\begin{array}{l}36.1 \\
(6.5)\end{array}$ & $\begin{array}{c}1.66 \\
(0.39)\end{array}$ & $\begin{array}{c}0.51 \\
(0.11)\end{array}$ & 10 \\
\hline FC1 & $\mathrm{OgPF}$ & & & $\begin{array}{l}\text { Sphagnum riparium } \\
\text { Carex aquatilis } \\
\text { Carex limosa }\end{array}$ & $\begin{array}{c}4.3 \\
(0.0)\end{array}$ & $\begin{array}{l}35.2 \\
(2.5)\end{array}$ & $\begin{array}{c}3.99 \\
(0.51)\end{array}$ & $\begin{array}{r}0.76 \\
(0.05\end{array}$ & 9 \\
\hline $\mathrm{FC} 2$ & $\mathrm{OgPF}$ & & & $\begin{array}{l}\text { Sphagnum riparium } \\
\text { Carex paupercula } \\
\text { Carex aquatilis }\end{array}$ & $\begin{array}{c}4.4 \\
(0.2)\end{array}$ & $\begin{array}{l}32.1 \\
(0.8)\end{array}$ & $\begin{array}{c}1.26 \\
(0.05)\end{array}$ & $\begin{array}{c}0.51 \\
(0.04)\end{array}$ & 10 \\
\hline FC3 & TlsPF & $\begin{array}{l}\text { Sphagnum fuscum } \\
\text { Kalmia polifolia } \\
\text { Larix laricina }\end{array}$ & $\begin{array}{l}\text { Cladopor } \\
\text { Sphagmu } \\
\text { Vacciniut }\end{array}$ & $\begin{array}{l}\text { Autans } \\
\text { stifolium } \\
\text { coccus }\end{array}$ & $\begin{array}{c}4.7 \\
(0.1)\end{array}$ & $\begin{array}{l}31.7 \\
(0.7)\end{array}$ & $\begin{array}{c}1.39 \\
(0.05)\end{array}$ & $\begin{array}{c}0.58 \\
(0.01)\end{array}$ & 21 \\
\hline $\mathrm{FC4}$ & $\mathrm{OgF}$ & & & $\begin{array}{l}\text { Warnstorfia exannulata } \\
\text { Carex limosa } \\
\text { Carex aquatilis }\end{array}$ & $\begin{array}{c}5.9 \\
(0.2)\end{array}$ & $\begin{array}{l}59.9 \\
(1.9)\end{array}$ & $\begin{array}{c}7.66 \\
(0.52)\end{array}$ & $\begin{array}{c}1.58 \\
(0.45)\end{array}$ & 20 \\
\hline $\mathrm{RBC}$ & $\mathrm{OgB}$ & & & $\begin{array}{l}\text { Sphagnum riparium } \\
\text { Eriophorum spissum } \\
\text { Carexpaupercula }\end{array}$ & $\begin{array}{c}3.9 \\
(0.1)\end{array}$ & $\begin{array}{l}37.1 \\
(2.4)\end{array}$ & $\begin{array}{c}1.72 \\
(0.89)\end{array}$ & $\begin{array}{c}0.41 \\
(0.14)\end{array}$ & 15 \\
\hline $\mathrm{TF} 2$ & $\mathrm{TtsF}$ & $\begin{array}{l}\text { Larix laricina } \\
\text { Sphagnum warnstorfii } \\
\text { Tomenthypnum nitens } \\
\text { Salix pedicillaris }\end{array}$ & $\begin{array}{l}\text { Limprich } \\
\text { Menyant } \\
\text { Salix ped } \\
\text { Callierge }\end{array}$ & $\begin{array}{l}\text { olvens } \\
\text { foliata } \\
\text { is } \\
\text { inteum }\end{array}$ & $\begin{array}{c}6.7 \\
(0.1)\end{array}$ & $\begin{array}{r}134.8 \\
(3.4)\end{array}$ & $\begin{array}{l}15.53 \\
(0.86)\end{array}$ & $\begin{array}{c}5.43 \\
(0.04)\end{array}$ & 47 \\
\hline TF4 & OlsF & $\begin{array}{l}\text { Sphagnum warnstorfii } \\
\text { Betula pumila var. gland } \\
\text { Salix pedicillaris }\end{array}$ & dulifera & $\begin{array}{l}\text { Scorpidium scorpioides } \\
\text { Menyanthes trifoliata } \\
\text { Andromeda glaucophylla }\end{array}$ & $\begin{array}{c}6.9 \\
(0.1)\end{array}$ & $\begin{array}{r}121.8 \\
(7.9)\end{array}$ & $\begin{array}{l}14.59 \\
(0.13)\end{array}$ & $\begin{array}{c}5.05 \\
(0.07)\end{array}$ & 47 \\
\hline $\mathrm{ZF} 1$ & $\mathrm{OlsF}$ & $\begin{array}{l}\text { Sphagnum fiuscum } \\
\text { Ledum groenlandicum } \\
\text { Picea mariana } \\
\text { Rubus chamaemorus }\end{array}$ & $\begin{array}{l}\text { Limprich } \\
\text { Salix ped } \\
\text { Carex ch } \\
\text { Betula p }\end{array}$ & $\begin{array}{l}\text { olvens } \\
\text { is } \\
\text { hiza } \\
\text { ar. glandulifera }\end{array}$ & $\begin{array}{c}5.9 \\
(0.2)\end{array}$ & $\begin{array}{c}71.3 \\
(11.5)\end{array}$ & $\begin{array}{c}2.84 \\
(1.42)\end{array}$ & $\begin{array}{c}1.01 \\
(0.47)\end{array}$ & 36 \\
\hline $\mathrm{ZF} 2$ & OlsF & $\begin{array}{l}\text { Tomenthypnum nitens } \\
\text { Sphagnum warnstorfii } \\
\text { Salix pedicillaris }\end{array}$ & $\begin{array}{l}\text { Limprich } \\
\text { Meesia t } \\
\text { Carex te } \\
\text { Menyant }\end{array}$ & $\begin{array}{l}\text { olvens } \\
a \\
a \\
\text { foliata }\end{array}$ & $\begin{array}{c}6.2 \\
(0.2)\end{array}$ & $\begin{array}{l}63.2 \\
(4.0)\end{array}$ & $\begin{array}{c}5.99 \\
(1.09)\end{array}$ & $\begin{array}{c}2.78 \\
(0.58)\end{array}$ & 32 \\
\hline $\mathrm{ZF3}$ & $\mathrm{OgF}$ & $\begin{array}{l}\text { Sphagnum warnstorfii } \\
\text { Salix pedicillaris } \\
\text { Carex rostrata }\end{array}$ & & $\begin{array}{l}\text { Sphagnum riparium } \\
\text { Warnstorfia exannulata } \\
\text { Carex rostrata } \\
\text { Potentilla palustris }\end{array}$ & $\begin{array}{c}5.8 \\
(0.1)\end{array}$ & $\begin{array}{l}55.1 \\
(5.1)\end{array}$ & $\begin{array}{c}5.77 \\
(0.99)\end{array}$ & $\begin{array}{c}2.27 \\
(0.03)\end{array}$ & 27 \\
\hline
\end{tabular}

Classes are $\mathrm{O}=$ Open; $\mathrm{T}=$ Treed; $\mathrm{ts}=\mathrm{tall}$ shrub; $\mathrm{ls}=$ low shrub; $\mathrm{g}=$ graminoid; $\mathrm{B}=\mathrm{Bog} ; \mathrm{F}=\mathrm{Fen} ; \mathrm{PF}=$ Poor Fen. Sites: $\mathrm{BC}=$ bog collapse scar; $\mathrm{FC}=$ fen collapse scar; $\mathrm{RBC}=$ remote bog collapse scar; $\mathrm{TF}=$ tower fen; $\mathrm{ZF}=\mathrm{Zoltai}$ fen. Major bryophyte and vascular plant species are listed for each microtopographic category within the site. Mean values (standard deviations) for $\mathrm{pH}$, corrected conductivity $\left(K_{\text {corn }} \mu \mathrm{S} / \mathrm{cm}\right)$, calcium $(\mathrm{Ca}, \mathrm{mg} / \mathrm{L}$ ), and magnesium $(\mathrm{Mg}, \mathrm{mg} / \mathrm{L}$ ) are listed with total number of species per site.

important developments for $\mathrm{CH}_{4}$ emission in the zone of discontinuous permafrost. Collapse scars are common across western Canada and may indicate that permafrost degradation is greater than aggradation in certain areas [Vitt et al., 1994]. Although the evolution of these features is poorly understood, there is some evidence that fire as well as long-term temperature trends may initiate collapse [Zoltai, 1993].

Peat plateaus in this study were always wooded and had negligible $\mathrm{CH}_{4}$ fluxes. These features were dry and well-drained with ground cover of lichens and feathermosses (e.g., Cladina 


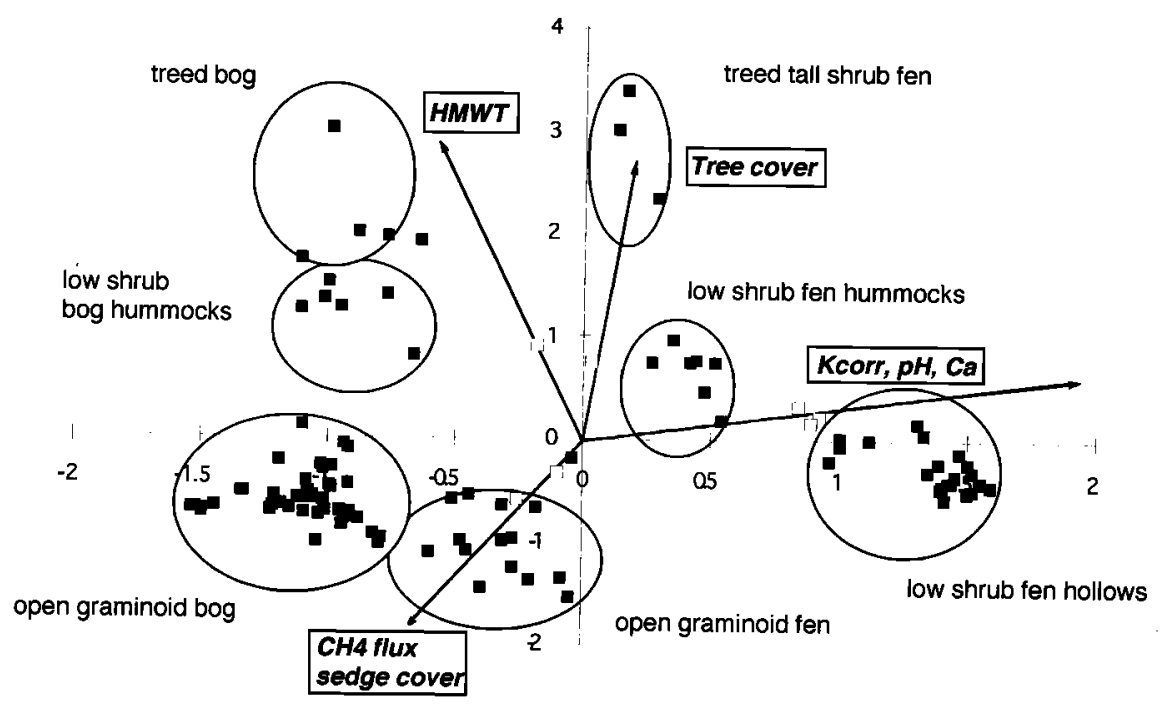

carpets and pools

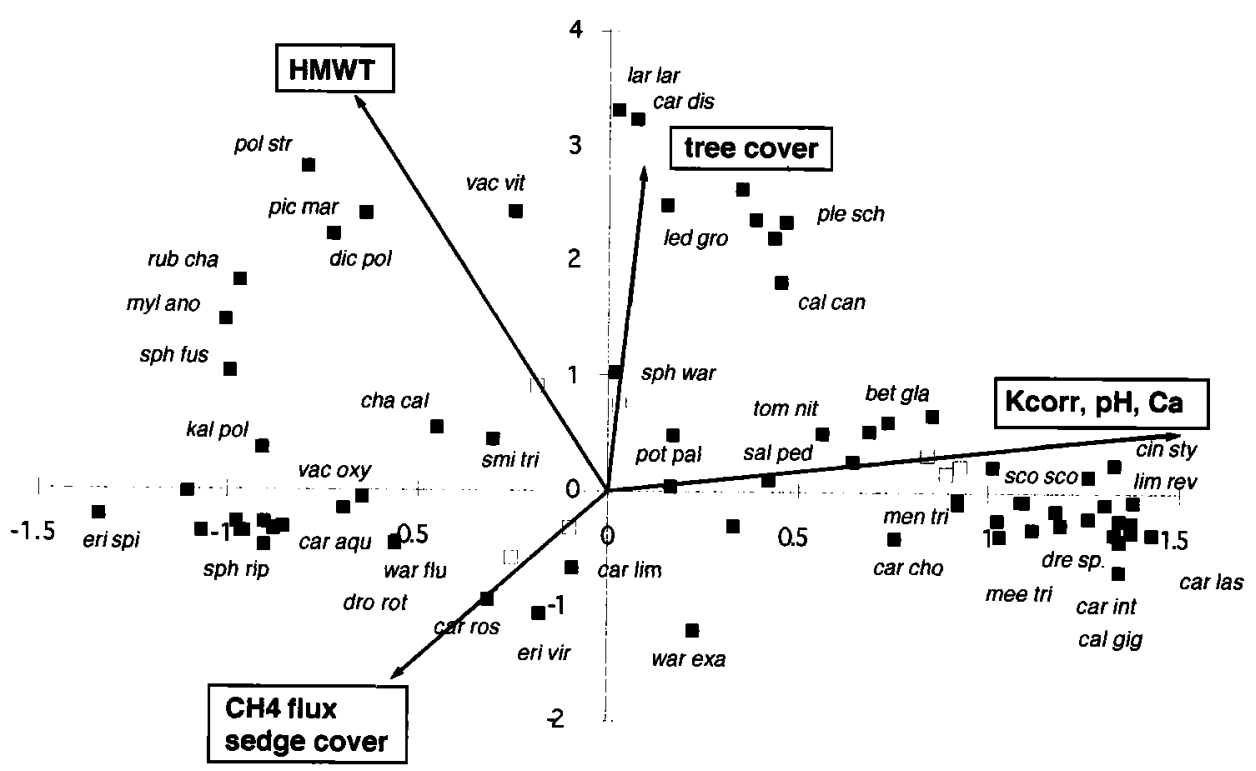

Figure 8. Canonical correspondence analysis (CCA) of vascular and bryophyte samples, species and environmental variables. (a) Solid boxes on the sample biplot represent individual collars; vegetation classes and microtopographic groupings are circled; (b) solid boxes on the species biplot represent the center of each species distribution based on weighted average abundances. The vectors (drawn from open boxes) represent environmental variables increasing in the positive direction from the center $(0,0$ point $)$ of the biplot. Negative values of environmental variables are inferred by extending the vectors in the opposite direction. Eigenvalues for axes 1,2 , and 3 are $0.72,0.54$, and 0.43 . Interset correlations for $\mathrm{pH}, \mathrm{Ca}$ and $K_{\text {corr }}$ with axis 1 are 894,861 and 814 , respectively. Interset correlations for HMWT, tree cover, sedge cover and $\mathrm{CH}_{4}$ flux with axis 2 are 837 , $687,-633$, and -546 , respectively. First three letters of genus and species are used for abbreviations in Figure $8 \mathrm{~b}$. See appendix for complete names.

spp. Pleurozium schreberi, Hylocomium splendens). Collapse scars ranged from bog to intemediate fen, depending on the location of the collapse and influence of groundwater. Regardless of chemistry, collapse scars had the highest emissions at the most saturated lagg areas near the edges of the frozen peat plateaus and were dominated by Sphagnum riparium or Warnstorfia exannulata (Tables 1 and 3). These sites also had the highest pulses of $\mathrm{CH}_{4}$ in spring and highest sedge density. The lagg areas on the outside edges of peat plateaus adjacent to unfrozen fens also had high $\mathrm{CH}_{4}$ emissions (Figure 5). During the season, large pulses (both bubbles and large diffusive fluxes) of $\mathrm{CH}_{4}$ were observed in the collapse scars that were not recorded at other 
sites. This data set may underestimate $\mathrm{CH}_{4}$ flux in the collapse scars because we may have missed some the large fluxes by sampling on a weekly basis.

The implications for these large $\mathrm{CH}_{4}$ emissions from collapse scars is that they may be a positive climate feedback. It does not seem to matter whether the collapse scars are bogs or fens in terms of large $\mathrm{CH}_{4}$ flux as long as both are saturated and sedgedominated. Over time, however, fen collapses may maintain saturated conditions longer if the influx of groundwater persists. In addition to saturation and sedge dominance, these areas were the warmest sites with seasonal average temperatures of 12 to $14^{\circ} \mathrm{C}$, even though they occurred adjacent to frozen peat. In contrast, the drier centers of the collapse scars away from the peat plateau-collapse interface had seasonal mean temperatures at the water table of 5 to $12^{\circ} \mathrm{C}$. The lagg areas also had floating peat surfaces, which maintained the anaerobic zone of methane production longer into the season.

Comparison of $\mathrm{CH}_{4}$ flux with other regions and predictive models. Even though 1994 was a drier than average year, the $\mathrm{CH}_{4}$ fluxes were higher than reported in many other boreal wetland studies. The relationship between water table and $\mathrm{CH}_{4}$ flux from a range of northern wetland locations [Moore and Roulet, 1993] showed that the slopes of the regression lines were not significantly different between regions, ranging from 0.022 to 0.037 . In this study (Figure $7 \mathrm{~b}$ ), the slope of the regression was 0.030 (if HMWT is expressed in centimeters rather than millimeters), which falls in the middle of the range of Canadian sites. This suggests that there is a similar functional relationship between $\mathrm{CH}_{4}$ flux and water table depth in a large range of peatlands. However, the Canadian study found that the intercepts were significantly different, ranging from 0.47 to 1.89 , suggesting that the magnitude of fluxes varied between regions. The differences were not related to latitude or temperature; Churchill, the most northerly site, had higher fluxes than Dorset in southern Ontario. The intercept for the Thompson peatlands in this study was 2.01 , which was higher than any of the other Canadian study sites. The differences could be related to the ability of the peat to produce or consume methane [Moore et al., 1994], but preliminary analyses of the Thompson data indicate that peat type is not related to flux strength. Collapse scar peats had consistently low $\mathrm{CH}_{4}$ production potentials in incubation experiments even though they were found in high flux sites. (J.L. Bubier and L. Bellisario, unpublished data, 1995).

The strongest predictive relationship in this study was mean temperature at the average position of the water table (Figure 7a). This variable combined both moisture and temperature, which other studies have found to be the two most important explanatory variables as well [Roulet et al., 1992a; Dise et al., 1993]. Methane production requires anaerobic conditions, but temperature controls the rate of production. In a collation of several boreal wetlands, Crill et al. [1992] found that temperature was a strong predictor of $\mathrm{CH}_{4}$ flux across a range of sites. In laboratory experiments, Dunfield et al. [1993] found that methanogenesis was weak at $<10^{\circ} \mathrm{C}$. The temperature dependence of methane production was strong, with $\mathrm{Q}_{10}$ values between 3 and 7 . In contrast, methane consumption showed a weaker temperature dependence, with $Q_{10}$ values between 1 and 2. Therefore at low temperatures, fluxes are probably low because production rates are slow below $10^{\circ} \mathrm{C}$ and consumption may still be relatively fast.
The combined variable of temperature and water table in this study incorporated microtopographic differences in $\mathrm{CH}_{4}$ flux . Since the temperature regime is largely controlled by the heat capacity of water in peatlands, a variable combining the two parameters may be a useful approach. In this study, the combined variable was a better predictor than either variable alone and identified the most important zone in the peat profile for methane production and consumption. The relationship between temperature at a standard depth (e.g., 10 or $20 \mathrm{~cm}$ ) and $\mathrm{CH}_{4}$ flux produced much weaker relationships because the thermal regime was significantly different between hummocks and hollows (Figures 2 and 3 ). In laboratory experiments of other northern peats, most of the $\mathrm{CH}_{4}$ was produced and consumed near the water table [Bubier et al., 1993a], and temperature was less important than water table when each was manipulated independently [Moore and Dalva, 1993].

The multiple regression model in this study combined moisture, temperature, chemistry, and vegetation characteristics. The peatland complex in the Thompson covered the full range of gradients found in northern peatlands. Temperature ranged from 0 to $16^{\circ} \mathrm{C}$; $\mathrm{pH}$ from 3.9 to 7.0 ; water table position from $50 \mathrm{~cm}$ to flooded; plant communities from wooded to open, Sphagnum versus brown moss, and sedge versus shrub. After temperature and water table were accounted for, chemistry $\left(K_{\mathrm{corr}}, \mathrm{pH}\right.$, and $\mathrm{Ca}$ ) and plant type (sedge, tree, herbaceous cover) improved the model (Table 3 ). Even though open graminoid fens had the highest $\mathrm{CH}_{4}$ fluxes, water chemistry was negatively correlated with $\mathrm{CH}_{4}$ flux. In a closer examination of vegetation data (see below), the highest $\mathrm{CH}_{4}$ fluxes were associated with poor and intermediate fens, not the rich fens. A similar pattern was observed in Schefferville, Quebec [Bubier, 1995], where the richest fens had relatively low fluxes given their flooded condition. In that case, as well as in this study, oxidation of $\mathrm{CH}_{4}$ may be occurring within the water column because of the stronger influence of groundwater in rich fen systems (N. Roulet, personal communication, 1994). In the Hudson Bay Lowlands, $\mathrm{pH}$ was not related to $\mathrm{CH}_{4}$ flux because the highest emissions occurred in degrading pools of open bogs [Moore et al., 1994].

Multivariate analyses of vegetation and remote sensing. Several studies have used wetland classifications in order to extrapolate $\mathrm{CH}_{4}$ emissions from the chamber to the landscape scale [e.g., Bartlett et al., 1989; Roulet et al., 1994]. Although this has been a successful strategy in some regions, it may be inadequate in other regions. For example, some wetlands of the boreal region are dominated by trees and have significantly different ranges in $\mathrm{CH}_{4}$ flux within the overall category of treed wetlands because of varying conditions of moisture and temperature [e.g., Bubier et al., 1993b]. Classifications are usually based on vegetation physiognomy and chemistry, and rarely incorporate microtopography and hydrology. As demonstrated in this study (Figures 5 and 6), the variability in $\mathrm{CH}_{4}$ fluxes within each of these broad physiognomic groupings can be large. Multivariate analyses of vegetation data are useful tools for refining the classifications because they reveal gradients and groupings in the vegetation that may be more relevant to the spatial variability in $\mathrm{CH}_{4}$ flux. Gradient analysis also shows the direct relationship between process-oriented environmental variables and plant distribution. The multiple regression model in this study showed that mean temperature and water table position were the most important environmental variables explaining $\mathrm{CH}_{4}$ 
flux, but these cannot be sensed remotely. Relating vegetation directly to the processes controlling $\mathrm{CH}_{4}$ flux provides a rationale for using vegetation to extrapolate $\mathrm{CH}_{4}$ fluxes.

In this study, CCA analyses showed that treed sites (Picea mariana) were consistently associated with dry conditions and low $\mathrm{CH}_{4}$ flux, and that sedge-dominated sites were correlated with high $\mathrm{CH}_{4}$ flux and saturated conditions (Figure 8). $\mathrm{CH}_{4}$ flux increased with greater sedge density, in this case mostly Carex and Eriophorum species. The variability in $\mathrm{CH}_{4}$ flux for graminoid poor fen and fen sites in Figure 6 could be explained by gradients in sedge cover. Shrub dominated areas were less predictive of $\mathrm{CH}_{4}$ flux because different species had a wider range of moisture habitats than either sedges or trees. Microtopography was more important in terms of $\mathrm{CH}_{4}$ flux in the intermediate moisture sites, with hummock and hollow sites separated along the moisture gradient. Microtopography was less important in treed sites, where $\mathrm{CH}_{4}$ fluxes were consistently low in hollows as well as hummocks, probably because the temperatures in treed sites were consistently lower (e.g. TF2, Table 1). This information is useful for remote sensing because it identifies the scale of variability necessary for spatial extrapolation and clarifies which lifeforms are better predictors of $\mathrm{CH}_{4}$ flux for classification purposes.

Compared with multivariate analyses of $\mathrm{CH}_{4}$ and vegetation data in other northern regions [Bubier, 1995], this study shows more promise for successful spatial extrapolations and remote sensing. In studies of boreal wetlands in Ontario and Quebec, vascular plants responded differently to the $\mathrm{CH}_{4}$ gradient than bryophytes. For example, in the Clay Belt region of Ontario, treed sites covered a large range of moisture, temperature, and $\mathrm{CH}_{4}$ flux conditions. Bryophytes, which were more sensitive to microtopographic differences in water table position, were much better predictors of $\mathrm{CH}_{4}$ flux [Bubier et al., 1995]. In Schefferville, Quebec, overall sedge cover was not a good predictor of $\mathrm{CH}_{4}$ flux because the drier strings of the patterned fens were dominated by Scirpus cespitosus, indicating low $\mathrm{CH}_{4}$ fluxes. On the other hand, Carex species dominated the wetter sites, indicating high $\mathrm{CH}_{4}$ emissions. The sedges had to be identified to genus to be useful in $\mathrm{CH}_{4}$ prediction.

In this study, the combined vascular and bryophyte analyses were more useful for explaining vegetation-environment gradients than either lifeform separately. Trees were consistent indicators of low $\mathrm{CH}_{4}$ flux. Sites with high sedge density were usually saturated environments vegetated by Carex or Eriophorum species. Other studies have found high $\mathrm{CH}_{4}$ emissions associated with Carex in flooded conditions (e.g. Carex rostrata, Bartlett et al. [1992]). These sedges may be important enhancers of $\mathrm{CH}_{4}$ emission because of their ability to transport $\mathrm{CH}_{4}$ through plant structures, bypassing the oxidation zone in the peat [Chanton et al., 1992; Chanton and Dacey, 1991; Whiting and Chanton, 1992]. They may also be associated with higher primary production, providing root exudates and a source of labile carbon for methanogenesis [Whiting and Chanton, 1993]. Sedges (esp. Carex rostrata, C. aquatilis, C. limosa, Eriophorum spp.) in this study were also dominant in the sites with floating peat surfaces, presumably because the water table remained relatively close to the peat surface even when the water table dropped overall. This has important implications for the role of floating peat surfaces and sedges on $\mathrm{CH}_{4}$ flux; once the water table drops below the peat surface (e.g. in a nonfloating environment), the relationship between sedge enhancement of $\mathrm{CH}_{4}$ flux through plant transport and production of root exudates may become decoupled (M. Waddington, unpublished data, 1995).

The bryophytes in this study were good indicators of $\mathrm{CH}_{4}$ flux on the microtopographic scale with Sphagnum fuscum, Polytrichum strictum, Pleurozium schreberi, hummock species, indicating low $\mathrm{CH}_{4}$ flux, and $S$. riparium, Warnstorfia exannulata and Cladopodiella fluitans, carpet species, indicating high flux. It may only be necessary to use bryophytes for predicting $\mathrm{CH}_{4}$ flux with remote sensing when the overall vegetation assemblages are not strongly predictive. Bryophytes have unique spectral signatures that can be distinguished in different habitats ( $\mathrm{J}$. Windsor, McGill University, 1993). For example, in the Thompson peatlands, bryophytes would be most useful for identifying microtopographic differences in moisture and $\mathrm{CH}_{4}$ status in the shrub-dominated sites, where vascular plants are less predictive of $\mathrm{CH}_{4}$ flux. They would be less important in the tree or sedge-dominated sites. As shown in the Cochrane and Schefferville studies, however, these relationships are not always the same in all boreal wetlands. Remote sensing of vegetation, therefore, would have to be calibrated to $\mathrm{CH}_{4}$ flux for the particular region.

\section{Conclusions}

$\mathrm{CH}_{4}$ emissions from this peatland complex were higher than observed in many other boreal regions [Moore and Roulet, 1993], even though 1994 was an abnormally dry year. The predictive model developed in this study showed the importance of the combined effect of temperature and moisture. Mean temperature at the average position of the water table, the most important zone in the peat profile for $\mathrm{CH}_{4}$ production and consumption, was the best overall predictor $\left(r^{2}=0.64\right)$. Chemistry and vegetation physiognomy improved the model and explained additional variance in $\mathrm{CH}_{4}$ flux $\left(r^{2}=0.81\right)$.

Multivariate analyses of vegetation data showed that gradients in plant communities can be important in identifying the scale of variability that would be necessary to extrapolate $\mathrm{CH}_{4}$ emissions from chambers to the landscape. These analyses make the direct link between species distribution and the environmental variables controlling $\mathrm{CH}_{4}$ flux. Because plant assemblages can be remotely sensed more easily than water table position or temperature, they are extremely useful predictors. Trees and sedges identified the lowest and highest ends of the $\mathrm{CH}_{4}$ flux gradient, because of the moisture and temperature environments that they represented, and because of the active role of sedges in enhancing $\mathrm{CH}_{4}$ emissions. Shrubs were less predictive and indicated more variable $\mathrm{CH}_{4}$ fluxes. In the shrub-dominated vegetation classes, bryophytes were useful in identifying the microtopographic variability in $\mathrm{CH}_{4}$ fluxes.

Finally, permafrost areas are susceptible to increasing $\mathrm{CH}_{4}$ emissions with the degradation of peat plateaus, which have very little $\mathrm{CH}_{4}$ emission, or in some cases, slight uptake. Other studies have found that the dynamic transition zones between terrestrial and aquatic environments are often the areas of highest $\mathrm{CH}_{4}$ emission [Bartlett et al., 1992; Crill et al., 1988; Moore et al., 1994]. Possible explanations include the continually saturated conditions in lagg areas of peatlands and the presence of aquatic plants that enhance $\mathrm{CH}_{4}$ flux through plant transport and root 
exudate production. This study shows that the dynamic boundary between permafrost features (palsas, peat plateaus) and lagg areas of fens and collapse scars also yields the highest $\mathrm{CH}_{4}$ emissions. The degradation of permafrost may have a positive feedback on climate through increased $\mathrm{CH}_{4}$ emissions and is an important aspect of landscape evolution for understanding trace gas dynamics.

Appendix: Dominant Vascular Plant, Bryophyte and Lichen Species Found in $\mathrm{CH}_{4}$ Sampling Collars

\section{Vascular plant species}

Andromeda glaucophylla

Betula pumila var. glandulifera

Betula papyrifera

Calamagrostis canadensis

Caltha palustris

Carex aquatilis

Carex canescens

Carex chordorrhiza

Carex diandra

Carex disperma

Carex gynocrates

Carex interior

Carex lasiocarpa

Carex leptalea

Carex limosa

Carex livida

Carex paupercula

Carex rostrata

Carex tenuiflora

Chamaedaphne calyculata

Coptis groenlandica

Cornus canadensis

Drosera anglica

Drosera rotundifolia

Epilobium palustre

Equisetum fluviatile

Eriophorum spissum

Eriophorum viridi-carinatum

Galium labradoricum

Habenaria dilitata

Juncus stygius

Kalmia polifolia

Larix laricina

Ledum groenlandicum

Lonicera villosa

Menyanthes trifoliata

Pedicularis parviflora

Picea mariana

Potentilla fruticosa

Potentilla palustris
Rubus chamaemorus

Salix pedicillaris

Salix serissima

Scirpus hudsonianus

Smilacina trifolia

Spiranthes romanzoffiana

Triglochin maritima

Utricularia intermedia

Vaccinium oxycoccus

Vaccinium vitis-idaea

\section{Bryophytes and Lichens}

Aulacomnium palustre
Bryum pseudotriquetrum
Calliergon giganteum
Calliergon stramineum
Campylium stellatum
Cinclidium stygium
Cladopodiella fluitans
Cladina mitis
Cladina stellaris
Dicranum polysetum
Dicranum undulatum
Drepanocladus aduncus
Hamatocaulis vernicosus
Hylocomium splendens
Hypnum lindbergii
Limprichtia revolvens
Lophozia ventricosa
Meesia triquetra
Mylia anomala
Plagiomnium ellipticum
Pleurozium schreberi
Pohlia nutans
Polytrichum strictum
Ptilium crista-castrensis
Ptilidium pulcherrimum
Scorpidium scorpioides
Sphagnum angustifolium
Sphagnum fuscum
Sphagnum magellanicum
Sphagnum riparium
Sphagnum subsecundum
Sphagnum warnstorfii
Tomenthypnum nitens
Warnstorfia exannulata
Warnstorfia fluitans

Acknowledgments. We thank Michele Culhane and Rob Swanson for superb field and laboratory assistance; Mike Dalva, Tim Finnegan, Carol Robinson, and Monique Simone for assistance with boardwalk construction; Jan Janssens and Cyrus McQueen for guidance on 
bryophyte identification and laboratory facilities; Steve Zoltai for discussions on permafrost dynamics; Nigel Roulet and three anonymous reviewers for valuable comments on the manuscript; NSERC and NASA grants for research on the BOREAS experiment.

\section{References}

Anderson, L. E., A checklist of Sphagnum in North America north of Mexico, The Bryologist, 93, 500-501, 1990.

Anderson, L. E., H. A. Crum, and W. R. Buck, List of the mosses of North America north of Mexico, The Bryologist, 93, 448-499, 1990.

Aselmann, I., and P. J. Crutzen, Global distribution of natural freshwater wetlands and rice paddies, their net primary productivity, seasonality and possible methane sources, J. Atmos. Chem., 8, 307-358, 1989.

Bartlett, K. B., and R. C. Harriss, Review and assessment of methane emissions from wetlands, Chemosphere, 26, 261-320, 1993.

Bartlett, D. S., K. B. Bartlett, J. M. Hartman, R. C. Harriss, D. I. Sebacher, R. Pelletier-Travis, D. D. Dow, and D. P. Brannon, Methane emissions from the Florida Everglades: Patterns of variability in a regional wetland ecosystem, Global Biogeochem. Cycles, 3, 363-374, 1989.

Bartlett, K. B., P. M. Crill, R. L. Sass, R. C. Harriss, and N. B. Dise, Methane emissions from tundra environments in the YukonKuskokwim Delta, Alaska, J. Geophys. Res., 97, 16,645-16,660, 1992.

Boone, D. R., Ecology of methanogenesis, in Microbial Production and Consumption of Greenhouse Gases: Methane, Nitrogen Oxides, and Halomethanes, edited by J.E. Rogers and W.B. Whitman, pp. 57-80, Am. Soc. Microbiol., Washington D. C., 1991.

Bubier, J. L., The relationship of vegetation to methane emission and hydro-chemical gradients in northern peatlands, $J$. Ecol., 83, 403 420,1995 .

Bubier, J., A. Costello, T. R. Moore, N. T. Roulet, and K. Savage, Microtopography and methane flux in boreal peatlands, northern Ontario, Canada, Can. J. Bot., 71, 1056-1063, 1993 a.

Bubier, J. L., T. R. Moore, and N. T. Roulet, Methane emissions from midboreal wetlands of northern Ontario, Canada, Ecol., 74, 22402254, 1993b.

Bubier, J. L., T. R. Moore, and S. Juggins, Predicting methane emission from bryophyte distribution in northern Canadian peatlands, Ecol., 76, 677-693,1995.

Chanton, J. P., and J. W. H. Dacey, Effects of vegetation on methane flux, reservoirs, and carbon isotopic composition, in Trace Gas Emissions From Plants, pp. 65-92, Academic, San Diego, Calif., 1991.

Chanton, J. P., C. S. Martens, C. A. Kelley, P. M. Crill, and W. J. Showers, Methane transport mechanisms and isotopic fractionation in emergent macrophytes of an Alaskan tundra lake, J. Geophys. Res. 97, 16,681-16,688, 1992.

Crill, P. M., K. B. Bartlett, R. C. Harriss, E. Gorham, E. S. Verry, D. I. Sebacher, L. Madzer, and W. Sanner, Methane flux from Minnesota peatlands, Global Biogeochem. Cycles, 2, 371-384, 1988.

Crill, P. M., R. C. Harriss, and K. B. Bartlett, Methane fluxes from terrestrial wetland environments, in Microbial Production and Consumption of Greenhouse Gases: Methane, Nitrogen Oxides, and Halomethanes, edited by J.E. Rogers and W.B. Whitman, pp. 91-110, Am. Soc. Microbiol., Washington D. C., 1991.

Crill, P.M. , K. B. Bartlett, and N. Roulet, Methane flux from boreal peatlands, Suo, 43, 173-182, 1992.

Daubenmire, R. F., Plant Communities:A Textbook of Plant Synecology, HarperCollins, New York, 1968.

Dise, N. B., E. Gorham, and E. S. Verry, Environmental factors controlling methane emissions from peatlands in northern Minnesota, J. Geophys. Res., 98, 10,583-10,594, 1993.

Dunfield, P., K. Knowles, R. Dumont, and T. Moore, Methane production and consumption in temperate and subarctic peat soils: response to temperature and pH, Soil Biol. Biochem., 25, 321-326, 1993.
Fernald, M. L., Gray's Manual of Botany, Van Nostrand Reinhold, New York, 1950. Reprint published by Dioscorides, Portland, Ore., 1987.

Frolking, S., and P. Crill, Climate controls on temporal variability of methane flux from a poor fen in southeastern New Hampshire: measurement and modeling, Global Biogeochem. Cycles, 8, 385-397, 1994.

Hansen, J., I. Fung, A. Lacis, D. Rind, S. Lebedeff, R. Ruedy, G. Russell, and P. Stone, Global climate changes as forecast by Goddard Institute for Space Studies three-dimensional model, J. Geophys. Res., 93, 9341-9364, 1988.

Moore, T. R., and M. Dalva, Influence of temperature and water table position on carbon dioxide and methane emissions from columns of peatland soils, J. Soil Sci., 44, 651-664, 1993.

Moore, T. R., and N. T. Roulet, A comparison of dynamic and static chambers for methane emission measurements from subarctic fens, Atmos. Ocean, 29, 102-109, 1991.

Moore, T. R., and N. T. Roulet, Methane flux: Water table relations in northern wetlands, Geophys. Res. Lett., 20, 587-590, 1993.

Moore, T. R., A. Heyes, and N. T. Roulet, Methane emissions from wetlands, southern Hudson Bay lowland, J. Geophys. Res., 99, 14551467, 1994.

Riley, J. L., Peat and Peatland Resources of Northeastern Ontario, Ontario Geol. Surv., Ministry of Northern Mines and Develop., Toronto, 1987.

Roulet, N., S. Hardill, and N. Comer, Continuous measurement of the depth of water table (inundation) in wetlands with fluctuating surfaces, Hydrol. Proc., 5, 399-403, 1991.

Roulet, N., R. Ash, and T. R. Moore, Low boreal wetlands as a source of atmospheric methane, J. Geophys. Res., 97, 3739-3749, 1992a.

Roulet, N., T. R. Moore, J. Bubier, and P. Lafleur, Northern fens: Methane flux and climatic change, Tellus, 44B, 100-105, 1992b.

Roulet, N. T., A. Jano, C. A. Kelly, L. F. Klinger, T. R. Moore, R. Protz, J. A. Ritter, and W. R. Rouse, The role of the Hudson Bay lowland as a source of atmospheric methane, J. Geophys. Res., 99, 1439-1454, 1994.

Sjörs, H., On the relation between vegetation and electrolytes in Swedish mire waters, Oikos, 2, 241-258, 1950.

Stotler, R., and B. Crandell-Stotler, Checklist of liverworts and hornworts of North America, Bryologist, 80, 405-428, 1977.

Svensson, B. H., and I. Sundh, Factors affecting methane production in peat soils, Suo, 43, 183-190, 1992.

ter Braak, C. J. F., CANOCO-A FORTRAN Program for Canonical Community Ordination by [Partial][Detrended][Canonical] Correspondence Analysis, Principal Components Analysis and Redundancy Analysis (version 3.1), TNO Inst. of Appl. Comp. Sci., Wageningen, Netherlands, 1990.

Vitt, D. H., L. A. Halsey, and S. C. Zoltai, The bog landforms of continental western Canada in relation to climate and permafrost patterns, Arct. Alp. Res., 26, 1-13, 1994.

Whalen, S. C., and W. S. Reeburgh, A methane flux time series for tundra environments, Global Biogeochem. Cycles, 2, 399-409, 1988.

Whalen, S. C., and W. S. Reeburgh, Interannual variations in methane emissions: A four-year time-series at fixed sites, Global Biogeochem. Cycles, 6, 139-159, 1992.

Whiting, G. J., and J. P. Chanton, Plant-dependent $\mathrm{CH}_{4}$ emission in a subarctic Canadian fen, Global Biogeochem. Cycles, 6, 225-231, 1992.

Whiting, G. J., and J. P. Chanton, Primary production control of methane emission from wetlands, Nature, 364, 794-795, 1993.

Wilkinson, L., SYSTAT: The System for Statistics, SYSTAT Inc., Evanston, IL., 1990.

Zoltai, S. C., Wetland environments and classification, in Wetlands of Canada, pp. 3-26, Polyscience, Montreal, Quebec, Canada, 1988.

Zoltai, S. C., Cyclic development of permafrost in the peatlands of northwestern Alberta, Canada, Arct. Alp. Res., 25, 240-246, 1993. 
L. Bellisario, N.T. Comer, and T.R. Moore, Geography Department and Centré for Climate and Global Change Research, McGill University, 805 Sherbrooke St. W., Montreal, Quebec, H3A 2K6 Canada. (e-mail: lianneb@felix.geog.mcgill.ca; neil@felix.geog.mcgill.ca; moore@felix.geog.mcgill.ca)

J.L. Bubier, P.M. Crill, Complex Systems Research Center, Institute for the Study of Earth, Oceans, and Space, University of New Hampshire, Durham, NH 03824-3525. (e-mail: jbubier@kaos.unh.edu; patrick@kaos.unh.edu)

(Received June 5, 1995; revised July 25, 1995;

accepted August 3,1995 .) 